UNIVERSIDADE DE SÃO PAULO

ESCOLA DE ENFERMAGEM

\title{
O AGENTE COMUNITÁRIO DE SAÚDE E A SAÚDE MENTAL: PERCEPÇÕES E AÇÕES NA ATENÇÃO ÀS PESSOAS EM SOFRIMENTO MENTAL
}

GIANNE CARVALHO DE SOUSA

São Paulo 


\title{
GIANNE CARVALHO DE SOUSA
}

\section{O AGENTE COMUNITÁRIO DE SAÚDE E A SAÚDE MENTAL: PERCEPÇÕES E AÇÕES NA ATENÇÃO ÀS PESSOAS EM SOFRIMENTO MENTAL}

\begin{abstract}
Dissertação de Mestrado apresentada à Escola de Enfermagem da Universidade de São Paulo. Área de concentração Enfermagem em Saúde Coletiva
\end{abstract}

Orientadora: Prof ${ }^{\mathrm{a}}$ Dra ${ }^{\mathrm{a}}$ Renata Ferreira Takahashi

São Paulo 
Dedicatória

Aos meus pais Gervásio e Zélia, que me ensinaram desde cedo a importância de estudar. 


\section{Agradecimentos}

A todos os Agentes Comunitários de Saúde do Programa Saúde da Família/Zerbini - Região Sudeste, em especial aos que se propuseram a participar deste estudo. Muito obrigada.

À Renata Ferreira Takahashi, que aceitou uma "mentaleira" como orientanda e enfrentou as crises desta durante o percurso.

A todos os funcionários da Escola de Enfermagem, pela atenção e paciência ante as inúmeras solicitações.

À Andréia Carvalho, presença imprescindível na constituição desta autora.

A todos os integrantes da Equipe de Saúde Mental.

À Ariane Machado Palma, Renata Bellenzani e Priscilla Cavini, pelo apoio, cumplicidade e ouvidos atentos.

Às 'antigas' Rosângela Gomes de Souza e Valéria Pugliese, pelas consultorias, interlocuções desarrazoadas e pelo caminho percorrido juntas com muita alegria.

A todos os funcionários da UBS Reunidas I, pelo apoio cotidiano e ensinamentos que proporcionam no trabalho conjunto.

À Márcia Regina Kretzer, Carolina Magnani, Carmo Domingos Jatene Filho, Antonio Lancetti e Ramiro Fernandes Pedro, obrigada pelas possibilidades de estudo e apoio nestes tantos anos de PSF.

Ao Décio de Castro Alves, pelo apoio de sempre e todos os livros 'roubados' de sua estante.

Á Juliana Guisardi Pereira e Wania Regina Veiga Martines, força constante na caminhada. Obrigada. 
Aos Carvalhos, José Anchieta, Érika e Sérgio, pelo incentivo, correções e diagramações. Muitíssimo obrigada.

Ao Humberto Sartori, com quem aprendi os múltiplos sentidos de loucura e desrazão.

Aos mestres, em saúde mental e saúde coletiva, Fernanda Nicácio e Roberto Tykanori, Maria do Socorro Matos e Isamara Gouveia, com quem tive o privilégio de trabalhar.

E, enfim, ao mestre David Capistrano da Costa Filho, obrigada, obrigada... 
"(...) a saúde se mede pela normatividade (capacidade de se fixar novas normas) significa também que a vida não está preocupada só em

defender-se, limitando-se às normas que ela própria institui em condições determinadas, mas expandir-se, enfrentando riscos e nesse enfrentamento instituindo novas normas. A saúde não é só a capacidade de evitar catástrofes, mas também a de criar novas normas arriscando a própria vida. Há aí uma exuberância, criatividade e generosidade vitais que nos distanciam irremediavelmente da noção de saúde como estabilidade". 


\section{RESUMO}

Sousa GC. O Agente Comunitário de Saúde e a Saúde Mental: percepções e ações na atenção às pessoas em sofrimento mental. [dissertação]. São Paulo (SP): Escola de Enfermagem da Universidade de São Paulo, 2007.

A inserção de ações da Saúde Mental no Programa Saúde da Família (PSF) é recente e está restrita a alguns locais. O conhecimento existente acerca das atividades das Equipes de Saúde Mental no PSF é escasso, assim como sobre a atuação dos Agentes Comunitários de Saúde (ACS) no âmbito da Saúde Mental. Nessa perspectiva, a presente investigação, de natureza qualitativa, teve como objetivo verificar as concepções do ACS a respeito do sofrimento mental e identificar as ações que realiza após detectar pessoas com este tipo de sofrimento no território em que desenvolve suas atividades. O estudo foi norteado pelos pressupostos da estratégia do Programa Saúde da Família, da Reforma Psiquiátrica e da Vulnerabilidade. Os dados foram coletados através de entrevistas individuais e semi-estruturadas, com doze ACS de Unidades de Saúde da Família (USF) da região sudeste do município de São Paulo. Na análise temática dos dados foram definidos dois núcleos temáticos: a compreensão do sofrimento mental e as práticas dos ACS na atenção em saúde mental do PSF. As concepções sobre sofrimento mental estão relacionadas às formas de identificação, suas causas e tratamentos. O ACS identifica as situações de sofrimento mental através de solicitações dos usuários, por meio de informações das pessoas da comunidade e através da observação dos comportamentos das pessoas. Dentre as várias causas do sofrimento mental, os ACS destacam, como principais, as condições socioeconômicas, configuradas por uma vida marcada por privações e violência. As ações realizadas pelos ACS, no âmbito da Saúde Mental, são: complementar e aprofundar as informações sobre as famílias com pessoas em sofrimento mental, compartilhá-las com a Equipe de Saúde da Família e Equipe de Saúde Mental e participar da elaboração e execução das estratégias de atenção às famílias. Para o ACS estas estratégias devem contemplar, principalmente, a utilização de psicofármacos e a realização de atividades (trabalho, estudo, caminhadas entre outras). Os ACS referiram a emergência de sentimentos na atenção às pessoas em sofrimento mental, que podem compor barreiras a seu trabalho, como: medo de serem agredidos e de agirem de forma incorreta e dificuldades em se relacionar com o sofrimento das pessoas. Os ACS sugerem que haja mais capacitação e apoio para o desenvolvimento de seu trabalho. Conclui-se que as concepções dos ACS sobre sofrimento mental orientam a identificação das pessoas nessa situação, principalmente aquelas que não chegam espontaneamente aos serviços de saúde. A condição dos ACS, de moradores do mesmo território em que trabalham, Ihes proporciona um conhecimento diferenciado sobre o contexto das famílias, que muito contribui na identificação das situações de sofrimento mental bem como da elaboração das estratégias de ação. Pelas ações que desenvolvem no território, como promoção e atenção às pessoas com sofrimento mental e suas famílias, os ACS podem ser considerados protagonistas da Reforma 
Psiquiátrica Brasileira. Assim, a ampliação das ações de saúde mental no PSF deveria ocorrer em todo o território brasileiro.

Palavras-chave: Agente Comunitário de Saúde, Saúde Mental, Programa Saúde da Família. 


\section{ABSTRACT}

Sousa GC. The Community Health Agent and Mental Health: perceptions and actions in Mental Health People attention. [dissertation]. São Paulo (SP): Universidade de São Paulo Nursing School; 2007.

The introduction of Mental Health Team (MHT) in the Family Health Program (FHP) is recent and restricted to a few places. The knowledge about MHT activities in the FHP is limited and so are the Community Health Agents' (CHA) actions in mental health area. From this perspective, the present qualitative research aimed to examine the $\mathrm{CHA}$ conceptions about mental illness people and identify their actions after discovering people with this kind of illness in their work area. The research was based on the Family Health Program strategies, Brazilian Psychiatric Reform and Vulnerability. The data were collected from individual and semi-structured interviews with twelve $\mathrm{CHA}$ of Family Health Center (FHC) in the Southwest regions of São Paulo City. Two thematic centers were identified through thematic analysis: the mental illness identification and the CHA actions in FHP mental health attention. The conceptions about mental illness were connected to its forms of identification, causes and treatments. The CHA identified mental illness situations through people's solicitations, community information and observation of people's behaviour. Among some mental illness causes, the $\mathrm{CHA}$ emphasize the socioeconomic conditions, characterized by a poor life and violence. The CHA actions in mental health area are: to complete and deepen information about families whose members suffer from any mental illness, to share them with Family Health Team and Mental Health Team, and to take part in formulation and execution of family attention strategies. For CHA these strategies involve, mainly, use of medicine and performance of activities (job, study, walking etc.). The CHA referred to the emergence of feelings during the mental illness people attention process,, such as: fear of physical aggression, wrong actions and difficulties in dealing with suffering people, which can make it difficult. The CHA suggest that there is more education and technical support in the development of their job. In conclusion, the CHA conceptions about mental illness guide the identification of people with this problem, mainly people who do not spontaneously seek for health service help. Living in the same place where they work, give the $\mathrm{CHA}$ a special knowledge about family context, which contributes a lot in strategy action formulation. For their actions in promoting and giving attention to mental illness people and their families, the CHA can be considered Brazilian Psychiatric Reform entrepreneurs. So, mental health actions could be widely performed all over Brazil.

Key-words: Community Health Agent, Mental Health, Family Health Program. 


\section{RESUMEN}

Sousa GC. Agente Comunitario de Salud y Salud Mental: percepciones y acciones en la atención a las personas con sufrimiento mental. [tesis de maestría]. São Paulo (SP): Escuela de Enfermería de la Universidad de São Paulo, 2007.

La inserción de acciones de Salud Mental en el Programa Salud de la Familia (PSF) es reciente y está restricta a algunos locales. El conocimiento existente acerca de las actividades de los Equipos de Salud Mental en el PSF es escaso, así como los referentes a la actuación de los Agentes Comunitarios de Salud (ACS) en el ámbito de Salud Mental. En esa perspectiva, esta investigación, de naturaleza cualitativa, tuvo como objetivo verificar las concepciones de los ACS al respecto del sufrimiento mental e identificar las acciones que realiza después de detectar personas con este tipo de sufrimiento, en el territorio en que desarrollan sus actividades. Este estudio fue guiado por los principios de la estrategia del PSF, de la Reforma Psiquiátrica y de la Vulnerabilidad. Los datos fueron colectados usando entrevistas individuales y semi-estructuradas, que fueron aplicadas a doce ACS de Unidades de Salud de la Familia (USF) de la región sudeste del municipio de Sâo Paulo. En al análisis de los datos fueron definidos dos núcleos temáticos: la identificación del sufrimiento mental y las prácticas de los ACS en la atención en salud mental del PSF. Las concepciones sobre sufrimiento mental están relacionadas a las formas de identificación, sus causas y tratamientos. Los ACS identifican las situaciones de sufrimiento mental a través de solicitaciones de los usuarios, por medio de informaciones de las personas de la comunidad y a través de la observación de los comportamientos de las personas. Dentro de las varias causas del sufrimiento mental, los ACS destacan, como principales, las condiciones socio-económicas, configuradas por una vida marcada por privaciones y violencia. Las acciones realizadas por los ACS, en el ámbito de la Salud Mental son: complementar y profundar las informaciones sobre las familias de las personas con sufrimiento mental, compartirlas con el Equipo de Salud de la Familia y el de Salud Mental y participar de la elaboración y ejecución de las estrategias de atención a las familias. Para el ACS estas estrategias deben incluir, principalmente, la utilización de psicofármacos y la realización de actividades (trabajo, estudio, caminatas, entre otras). Los ACS refirieron el surgimiento de sentimientos en la atención a las personas con sufrimiento mental, que pueden componer barreras a la misma, como: miedo de ser agredidos y de actuar de forma incorrecta y, dificultades en relacionarse con el sufrimiento de las personas. Los ACS sugieren que haya más capacitación y apoyo para el desarrollo de su trabajo. Se concluye que las concepciones de los ACS sobre sufrimiento mental orientan la identificación de las personas en esa situación, principalmente a aquellas que no llegan espontáneamente a los servicios de salud. La condición de los ACS, de moradores del mismo territorio en que trabajan, les proporciona un conocimiento diferenciado sobre el contexto de las familias, que mucho contribuyen en la identificación de las situaciones de sufrimiento mental así 
como de la elaboración de las estrategias de acción. Por las acciones que realizan en el territorio, de promoción y atención a las personas con sufrimiento mental y sus familias, los ACS pueden ser considerados protagonistas de la Reforma Psiquiátrica Brasilera. Así, la ampliación de las acciones de salud mental en el PSF debería ocurrir en todo el territorio brasilero.

Palabras clave: Agente Comunitario de Salud, Salud Mental, Programa Salud de la Familia. 


\section{SUMÁRIO}

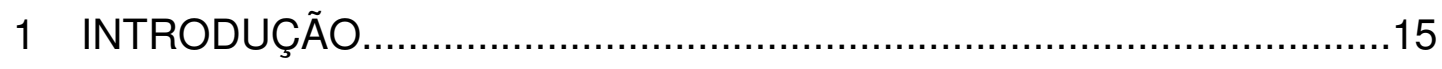

1.1 O Programa Saúde da Família..................................................

1.2 A atenção em Saúde Mental no Programa Saúde da Família.....20

1.3 Os Agentes Comunitários de Saúde...........................................31

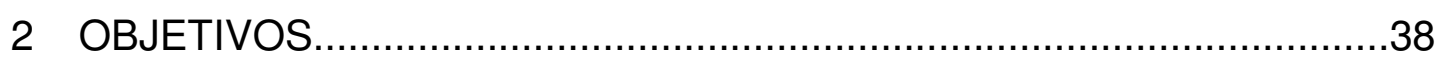

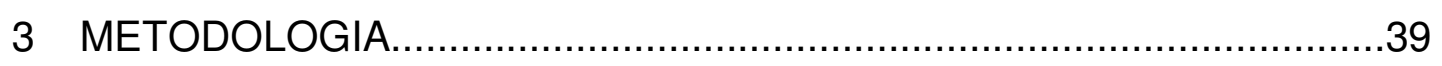

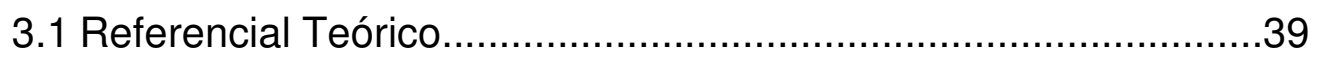

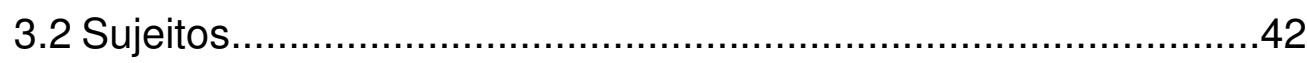

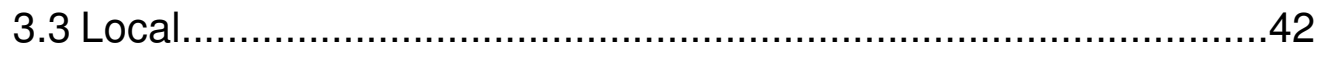

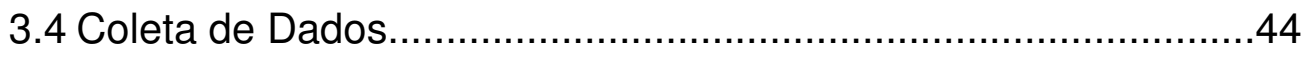

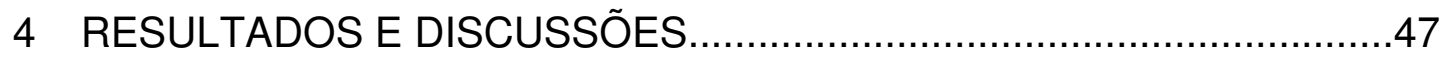

4.1 Caracterização da população estudada.......................................4

4.2 Núcleos temáticos................................................................50

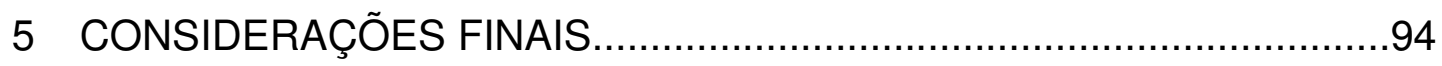

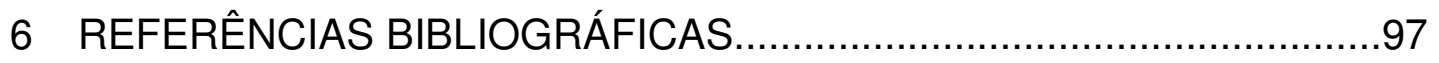

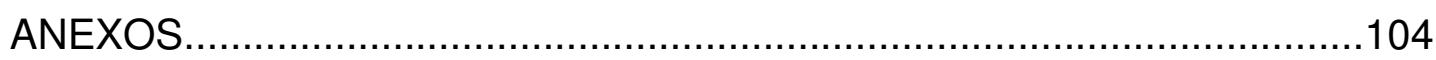




\section{APRESENTAÇÃo}

No início de 1998 concluí o curso de Aprimoramento Multiprofissional em Saúde Mental, durante o qual desenvolvi, por dois anos, atividades nos Núcleos de Atenção Psicossocial (NAPS) de Santos. Nesse município o Programa de Saúde Mental era referência nacional por consolidar os princípios da Reforma Psiquiátrica Brasileira com a extinção do manicômio e criação de serviços de atenção na comunidade.

No final desse mesmo ano, comecei a trabalhar no Programa Saúde da Família (PSF) do município de São Paulo, integrando a primeira Equipe de Saúde Mental (ESM) da região Sudeste com outros três psicólogos. Essa equipe foi criada com o objetivo de capacitar as Equipes de Saúde da Família (ESF) e prestar assistência às famílias em situação de sofrimento mental da área de abrangência das Unidades Básicas de Saúde (UBS) existentes nessa região. Tratava-se de uma proposta nova e, por isso, um desafio a ser superado.

Após um processo de sensibilização das ESF em relação à saúde mental, iniciamos a assistência em conjunto com elas, tendo a família como alvo da atenção.

No início, houve resistências das ESF quanto à inserção de ações de saúde mental no PSF, sendo imprescindível a intervenção dos coordenadores deste Programa, dos níveis central, local e de saúde mental, para o seu estabelecimento e manutenção.

Desde o início das atividades da ESM as ações realizadas com os Agentes Comunitários de Saúde (ACS), como os atendimentos domiciliares e discussão de casos, chamaram minha atenção. Eram eles que, geralmente, apresentavam as situações de sofrimento mental dos moradores do território para discussão nas reuniões de equipe e, também, 
acompanhavam os técnicos da ESM nas visitas domiciliares às famílias. As conversas durante as caminhadas até o domicílio das famílias compreendiam oportunidades para conhecer detalhes da situação da família foco da visita e entender como era para os ACS realizar este atendimento, suas impressões e receios na atenção em saúde mental.

Após algum tempo de atuação, despertou minha atenção a identificação de pessoas com sofrimento mental que, mesmo sendo moradoras do bairro há vários anos e cadastradas no PSF, não eram conhecidas pela ESM. Tratava-se de situações 'escondidas' no território que, se eram conhecidas pelos ACS, não eram encaminhadas para discussão com suas equipes de referência (ESF e ESM). A descoberta desses casos foi possibilitada pela procura espontânea dos usuários aos serviços de saúde decorrente da piora dos sintomas de sofrimento psíquico, ou do comentário de um vizinho em visitas domiciliares, até mesmo, por acaso.

Assim, ao me deparar com essa realidade - em que havia algumas situações de sofrimento mental no território que não eram conhecidas pela ESM, embora fossem cadastradas pelos ACS - surgiram alguns questionamentos sobre a atuação dos ACS no encaminhamento dessas situações, que deram origem à realização do presente estudo: quais situações de sofrimento mental eram levadas para discussão nas reuniões e quais não? Haveria algum receio de aproximar-se das famílias com portadores de sofrimento mental? Os ACS não sabiam identificar os portadores de sofrimento mental por desconhecer, por exemplo, os sintomas dos mesmos? Enfim, qual a compreensão dos ACS acerca de sofrimento mental e quais suas ações ao se depararem com tais situações? 


\section{INTRODUÇÃO}

$\mathrm{Na}$ década de 90 ocorreram mudanças significativas na área da saúde no Brasil. Após a regulamentação das Leis Federais no 8.080 e 8.142, que dispõem sobre o funcionamento do Sistema Único de Saúde (SUS) e o estabelecimento de critérios de operacionalização e repasse de recursos financeiros, através da Norma Operacional Básica (NOB), iniciou-se o processo de descentralização dos serviços, pelo qual os municípios passaram a ser os principais responsáveis pela gestão dos serviços de saúde (Bodstein, 2002).

Nesta década, a atenção à saúde da população passou por modificações com a expansão do Programa Saúde da Família (PSF) desencadeada pelos resultados positivos alcançados na região Nordeste do Brasil, acrescidos do incentivo financeiro do governo federal na priorização da atenção básica à saúde e das recomendações de organismos internacionais, como o Banco Mundial, de ofertar um pacote mínimo de serviços de saúde, acessível para a população brasileira (Misoczky, 1995; Lima, 1996; Weber, 2006).

No âmbito da Saúde Mental, a década de 90 foi marcada por avanços na consolidação da Reforma Psiquiátrica Brasileira com a realização da II Conferência Nacional de Saúde Mental em Brasília no ano de 1992 e com a expansão de serviços substitutivos ao hospital psiquiátrico, como os Centros de Atenção Psicossocial (CAPS), que passaram de 15 unidades em 1991 para 208 no ano 2000 (Brasil, 2007b).

\subsection{O Programa Saúde da Família}

A Organização das Nações Unidas (ONU) elegeu 1994 como o "Ano Internacional da Família". Nesse mesmo ano o PSF começou a ser implantado no Brasil e, em pouco mais de dez anos, se faz presente em 
92\% dos 5.564 municípios brasileiros, com 26.861 Equipes de Saúde da Família (ESF), dando cobertura a $46,4 \%$ da população brasileira (Brasil, 2007a).

O PSF foi elaborado como uma estratégia de reorientação do modelo assistencial à saúde, marcado até então pela prática hospitalocêntrica e uso irracional dos recursos tecnológicos disponíveis. Nessa estratégia se propôs que a atenção básica se configure como "porta de entrada" no Sistema de Saúde, sendo capaz de resolver $85 \%$ dos problemas de saúde da população adscrita no território de referência (Brasil, 2000).

Os objetivos do PSF são:

- Contribuir para a reorientação do modelo assistencial a partir da atenção básica, em conformidade com os princípios do Sistema Único de Saúde, imprimindo uma nova dinâmica de atuação nas unidades básicas de saúde, com definição de responsabilidades entre os serviços de saúde e população.

- Prestar, na unidade de saúde e no domicílio, assistência integral, contínua, com resolubilidade e boa qualidade às necessidades de saúde da população adscrita.

- Intervir sobre os fatores de risco aos quais a população está exposta.

- Eleger a família e o seu espaço social como núcleo básico de abordagem no atendimento à saúde.

- Humanizar as práticas de saúde através do estabelecimento de um vínculo entre os profissionais de saúde e a população.

- Propiciar o estabelecimento de parcerias através do desenvolvimento de ações intersetoriais.

- Contribuir para a democratização do conhecimento do processo saúde/doença, da organização dos serviços e da produção social da saúde. 
- Fazer com que a saúde seja reconhecida como um direito de cidadania e, portanto, expressão de qualidade de vida.

- Estimular a organização da comunidade para o efetivo exercício do controle social (Brasil, 1997).

Em termos operacionais a implantação do PSF nos municípios brasileiros é iniciada nas áreas mais carentes que, em geral, localizam-se na periferia dos mesmos e que contam com escassos serviços de saúde. Os profissionais que compõem as equipes básicas, ou Equipes de Saúde da Família (ESF), desse programa são: um médico generalista, um enfermeiro, um auxiliar de enfermagem e de quatro a seis ACS. Outros profissionais podem ser incluídos no PSF de acordo com a necessidade de cada região (Brasil, 2000). A inclusão de Equipes de Saúde Bucal conta, inclusive, com incentivo financeiro específico do Ministério da Saúde (MS). Cada ESF é responsável pela atenção de seiscentas a mil famílias de um determinado território de abrangência, não devendo ultrapassar o número de 4.500 pessoas em cada área (Brasil, 2004d).

As atribuições básicas das ESF são:

- conhecer a realidade das famílias pelas quais são responsáveis e identificar os problemas de saúde mais comuns e situações de risco aos quais a população está exposta;

- executar, de acordo com a qualificação de cada profissional, os procedimentos de vigilância à saúde e de vigilância epidemiológica, nos diversos ciclos da vida;

- prestar assistência integral, respondendo de forma contínua e racionalizada à demanda, buscando contactos com indivíduos sadios ou doentes, visando promover a saúde por meio da educação sanitária;

- promover ações intersetoriais e parcerias com organizações formais e informais existentes na comunidade para o enfrentamento conjunto dos problemas; 
- discutir, de forma permanente, junto à equipe e à comunidade, o conceito de cidadania, enfatizando os direitos de saúde e as bases legais que os legitimam;

- Incentivar a formação e/ou participação ativa nos conselhos locais de saúde e no Conselho Municipal de Saúde (Brasil, 2000, p.318-319).

Quanto à atribuição de "prestar assistência integral" é preciso esclarecer que, nas referências bibliográficas consultadas, ao termo integralidade se atribui mais de um sentido. Um destes se refere à organização dos serviços, ou seja, de acordo com os princípios do SUS, as práticas assistenciais podem ser curativas, de prevenção e promoção da saúde; a atenção integral deve contemplar, então, todos estes níveis de organização. Outro sentido refere-se à abordagem dos indivíduos como sujeito biopsicossocial (Alves, 2005).

A integralidade contrapõe-se à abordagem fragmentária e reducionista dos indivíduos. O olhar do profissional, neste sentido, deve ser totalizante, com apreensão do sujeito biopsicossocial. Assim, seria caracterizada pela assistência que procura ir além da doença e do sofrimento manifesto, buscando apreender necessidades mais abrangentes dos sujeitos (Alves, 2005, p. 42).

Ainda que a proposta do PSF tenha como um de seus pressupostos a atenção integral, as ações para grupos específicos da população são prioridades nesse programa, como: saúde da criança, saúde da mulher, controle da hipertensão arterial, diabetes e tuberculose e eliminação da hanseníase (Brasil, 2001). Estes são também os grupos prioritários de atenção à saúde a serem incluídos no pacote básico de saúde recomendado pelo Banco Mundial (Misoczky, 1995; Lima, 1996). 
O acompanhamento e o monitoramento deste extenso trabalho de atenção a mais de 86 milhões de brasileiros são realizados através da coleta de informações e alimentação de um banco de dados nacional, denominado de Sistema de Informações da Atenção Básica (SIAB). Este sistema é avaliado como bom, por permitir "a caracterização da situação sóciossanitária e do perfil epidemiológico e o acompanhamento das ações de saúde desenvolvidas" (Brasil, 1998a, p.5). No entanto, apresenta algumas inadequações e limitações, dentre as quais se destaca o elevado número de formulários a serem preenchidos, o despreparo das próprias equipes no manejo, análise e utilização destes dados e o conteúdo do registro dos agravos vinculados ao adoecimento mental (Brasil, 2004c).

No município de São Paulo, o maior município brasileiro, o processo de municipalização da gestão em saúde foi efetivado apenas em 2002. Por este motivo a implantação do PSF, a partir de 1995, se deu através de parcerias entre governo, MS e Secretaria Estadual de Saúde (SES), e instituições não governamentais.

Em 1995, iniciou-se a implantação do PSF na região leste do município de São Paulo através da parceria estabelecida entre o MS, SES e a Casa de Saúde Santa Marcelina. Neste município o PSF foi, a princípio, denominado de Qualidade Integral de Saúde (Qualis). Dois anos mais tarde, a parceria do MS, SES e Fundação Zerbini, possibilitou a expansão do PSF para outras duas regiões do município: Norte e Sudeste, sendo esta última o local onde foi realizado este estudo'.

Um diferencial desse PSF é que outras modalidades de atenção foram inseridas para garantir a assistência integral, no sentido de não cindir

\footnotetext{
${ }^{1}$ Será utilizada a denominação PSF/Zerbini para referir-se ao PSF onde o estudo foi realizado. A pareceria do MS, SES e Fundação Zerbini foi substituída por convênio entre esta Fundação e Secretaria Municipal de Saúde em 2002 com a municipalização dos serviços de saúde. Em março de 2007, com o fim do convênio, uma nova parceria foi firmada para garantir a continuidade de atenção à saúde da população. A opção pela denominação anterior deveu-se ao fato de ser a parceria com a Fundação Zerbini que estava vigente quando da realização do estudo.
} 
os problemas de saúde da população em biológicos, psicológicos e sociológicos (Capistrano, 1999). Foram constituídas Equipes de Saúde Mental (ESM), de Saúde Bucal e um Ambulatório de Especialidades para dar retaguarda de assistência nas duas regiões, Sudeste e Norte, nas quais o PSF/Zerbini foi implantado. Para a região Sudeste, foram acrescidas, ainda, duas outras modalidades: a Casa de Parto e a Equipe de Saúde do Deficiente.

Um dos critérios de escolha dos Distritos Administrativos para implantação do PSF em São Paulo foi o número de famílias com renda inferior ou igual a cinco salários mínimos (Elias, Nakamura, Cohn, 2003). Sua expansão ocorreu a partir de 2000, alcançando $22,1 \%$ da sua população em 2005 (São Paulo, 2005). Em algumas áreas as ESF estão incompletas pela dificuldade de encontrar técnicos, em especial médicos, que se disponham a trabalhar em locais de difícil acesso constituídos por "bolsões de expressão da violência" (Elias, Nakamura, Cohn, 2003, p.67).

\subsection{A Atenção em Saúde Mental no Programa Saúde da Família}

O modelo de atenção em Saúde Mental estabelecido no PSF coaduna com as diretrizes da Reforma Psiquiátrica Brasileira que constitui um processo social, cujo objetivo é

(...) não só tratar mais adequadamente o indivíduo com transtorno mental, mas o de construir um novo espaço social para a loucura, questionando e transformando as práticas da psiquiatria tradicional e das demais instituições da sociedade (Amarante 2003, p. 58).

Compreende, ainda, um movimento que teve início em 1978, quando médicos psiquiatras denunciaram ao Ministério da Saúde a ocorrência da violação dos direitos humanos em hospitais psiquiátricos federais. A partir 
desta situação foi constituído o Movimento dos Trabalhadores de Saúde Mental (MTSM) que, em pouco tempo, se expandiu por todo o país, e estimulou discussões relacionadas à assistência psiquiátrica em centros acadêmicos, sindicatos do setor saúde e outras instituições da sociedade civil. Organizaram-se vários eventos com a participação de instituições de expressão nacional, como o Centro de Estudos de Saúde (CEBES), o Instituto Brasileiro de Análises Sociais e Econômicas (IBASE), o Sindicato dos Médicos, a Ordem dos Advogados do Brasil (OAB), a Associação Brasileira de Imprensa (ABI) e a Conferência Nacional dos Bispos do Brasil (CNBB) (Amarante, 1995; Amarante, 1997; Amarante, 2003).

(...) o MTSM torna-se o primeiro e mais importante ator de renovação no campo da saúde mental, que vai estabelecer uma agenda para o setor que, sob o título de Reforma Psiquiátrica, introduz a estratégia da desinstitucionalização no âmbito das políticas públicas (Amarante, 1997, p. 163).

Embora várias experiências internacionais de Reforma Psiquiátrica, como a Comunidade Terapêutica na Inglaterra, a Psicoterapia Institucional e a Psiquiatria de Setor na França e, a Psiquiatria Comunitária ou Preventiva nos Estados Unidos, tenham influenciado a Reforma Psiquiátrica Brasileira, a principal influência, considerada referência teórica básica, foi a experiência italiana liderada por Franco Basaglia. Na Itália, em 1978, foi aprovada a Lei 180 “(...) que propõe, pela primeira vez na história, o fim do manicômio enquanto aparato psiquiátrico, e sua substituição por outros meios de cuidados e acolhimento" (Amarante, 1997, p. 178).

No Brasil, esta influência contribuiu para que a proposta, em curso até os dias de hoje, visasse a desconstrução da cultura manicomial de tutela, de estigma, da segregação e da desqualificação do sujeito com sofrimento 
psíquico $^{2}$. E, além disso, buscasse a substituição da assistência em hospitais pela atenção em outras modalidades de serviços de saúde da comunidade, que possibilitasse

(...) resgatar histórias, biografias e subjetividades dos sujeitos portadores de sofrimento psíquico", colocando em "debate a cidadania e os direitos humanos do doente e, mesmo, o direito a um verdadeiro e digno tratamento (Amarante, 1997, p. 165).

Em 1989 ocorreu a intervenção na Casa de Saúde Anchieta em Santos (SP), após a constatação de mortes e violência naquele local. Esta instituição foi progressivamente desmantelada e uma rede de serviços substitutivos, os Núcleos de Atenção Psicossocial (NAPS) com funcionamento 24 horas por dia em todos os dias da semana, foram instalados em cinco diferentes regiões do município. Esta experiência concretizou, no Brasil, a possibilidade de superação do modelo psiquiátrico tradicional, sendo referência nacional (Amarante,1997).

Outra influência para as propostas de Saúde Mental em curso foi a Conferência Regional sobre a Reestruturação da Atenção Psiquiátrica na América Latina que ocorreu em 1990, na Venezuela. Do encontro de legisladores, associações, autoridades sanitárias, profissionais de Saúde Mental e juristas resultou a Declaração de Caracas que propõe "o desenvolvimento da atenção psiquiátrica estreitamente vinculada à atenção primária de saúde" (OMS, 2001, p. 84).

\footnotetext{
${ }^{2}$ Há vários termos para designar os problemas mentais, neste estudo serão utilizados 'sofrimento mental' e 'sofrimento psíquico' para referir-se a tais problemas pois se coadunam com os pressupostos da Reforma Psiquiátrica Brasileira que nortearam este estudo. Diferentemente do termo 'doença mental', caracterizada como objeto do saber médico, e 'loucura', expressão genérica relacionada a quebra de padrões éticos, morais, sociais etc. (Amarante, 1997), a expressão 'sofrimento psíquico ou mental' se refere a sujeitos portadores de sofrimento e sua existência global, complexa e concreta com o corpo social (Rotelli, 1990).
} 
Em 1998, no município de São Paulo, se iniciou a inserção da assistência na área da Saúde Mental no PSF, com a formação de uma Equipe de Saúde Mental (ESM), junto às unidades de saúde do PSF existentes nas regiões Sudeste e Norte do município (Lancetti, 2000). Esta e outras experiências de Saúde Mental na atenção básica, desenvolvidas no Brasil, foram desencadeadoras da constituição de grupos de discussão, pelo MS, para debater a inserção de ações de Saúde Mental no PSF e no Programa Agentes Comunitários de Saúde (PACS); foram realizadas: a Oficina de Trabalho para "Discussão do Plano Nacional de Inclusão das Ações de Saúde Mental na Atenção Básica", em março de 2001; o Seminário Internacional sobre Saúde Mental na Atenção Básica, em abril de 2002 e a Oficina de Saúde Mental no VII Congresso Brasileiro de Saúde Coletiva - ABRASCO (Brasil, 2004c).

Comemorando dez anos do estabelecimento, pelas Organizações das Nações Unidas (ONU), dos direitos dos doentes mentais à proteção e assistência, o ano de 2001 foi dedicado à discussão da Saúde Mental no mundo. Neste ano, o Dia Mundial da Saúde teve por tema "Cuidar, sim. Excluir, não"; retomando o princípio outrora estabelecido de que "não deverá existir discriminação em virtude de doenças mentais" (OMS, 2001, p. 13).

Dentre as atividades desenvolvidas pela Organização Mundial de Saúde (OMS) ocorreu, neste mesmo ano, a apresentação do Relatório Mundial de Saúde 2001, também dedicado ao tema de Saúde Mental e apresentado em língua portuguesa na III Conferência Nacional de Saúde Mental do Brasil (III CNSM), realizada em Brasília em dezembro de 2001.

O Relatório apresenta, entre outros, a magnitude dos transtornos mentais e suas conseqüências econômicas em âmbito mundial. 
Os transtornos mentais e comportamentais ocorrem comumente e afetam mais de $25 \%$ da população em dada fase da sua vida. São também universais, afetando pessoas de todos os países e sociedades, indivíduos de todas as idades, mulheres e homens, ricos e pobres, gente de áreas urbanas e rurais. Exercem impacto econômico sobre as sociedades e sobre o padrão de vida das pessoas e das famílias. Os transtornos mentais e de comportamento estão presentes a qualquer momento em cerca de $10 \%$ da população adulta. Aproximadamente $20 \%$ de todos os pacientes atendidos por profissionais de atenção primária têm um ou mais transtornos mentais e comportamentais (OMS, 2001, p.45).

Diante da gravidade da situação epidemiológica dos transtornos mentais no mundo, a OMS elaborou as seguintes recomendações para orientar cada país na proposição da atenção ao portador de sofrimento mental:

Proporcionar tratamento na atenção primária; garantir o acesso aos psicotrópicos; garantir atenção na comunidade; educação em saúde para a população; envolver as comunidades, as famílias e os usuários; estabelecer políticas, programas e legislação nacionais; formar recursos humanos; criar vínculos com outros setores; monitorizar a saúde mental na comunidade e dar mais apoio à pesquisa (OMS, 2001, p.15-17).

Levantamentos epidemiológicos populacionais realizados no Brasil indicam que, no período de um ano, um em cada cinco adultos demandam algum tipo de cuidado médico devido aos transtornos mentais. Nas mulheres os transtornos mais comuns são de ansiedade e depressão e, entre os homens, o mais comum é a dependência do álcool. Os médicos generalistas são os que mais atendem as pessoas com transtorno 
psiquiátrico menor (transtorno de ansiedade, depressivos e somatoformes) (Mari, Jorge, 2002).

Dada a magnitude de problemas mentais na população brasileira, conclui-se que também as equipes da atenção básica se deparam em seu cotidiano com problemas relacionados à saúde mental. Assim como recomenda o Relatório Sobre a Saúde no Mundo 2001 (OMS,2001), a inclusão de ações de saúde mental na atenção básica foi tema discutido na III CNSM. A proposta aprovada recomenda a capacitação em saúde das equipes do PSF, a inclusão de equipes multiprofissionais de saúde mental para atender junto as ESF e inserção de ficha específica para coleta de dados sobre os portadores de sofrimento psíquico atendidos pelas ESF (Brasil, 2002b).

E, enfim, no ano de 2007, o MS apresentou o Relatório de Gestão 2003-2006 (Brasil, 2007) no qual se vislumbra a proposta de expansão das ações de Saúde Mental na Atenção Básica:

Não há dúvida de que a implantação, expansão e qualificação do apoio matricial é um dos principais desafios para a gestão da Política de Saúde Mental do país nos 4 próximos anos e para a garantia de acessibilidade à atenção, um dos maiores desafios do Sistema Único de Saúde. Do mesmo modo, o fortalecimento de uma política efetiva de formação continuada, que envolva tanto as equipes de Saúde Mental como as da atenção básica, deverá ser uma das principais prioridades se queremos dar conta de fato da integralidade do sujeito (Brasil, 2007, p.24). 
O apoio matricial em saúde mental para as ESF do PSF deve ser feito por equipes denominadas pelo MS de Equipe Matricial de Referência ${ }^{3}$.

O "matriciamento" consiste nas ações de supervisão, atendimento compartilhado e capacitação em serviço, realizado por uma equipe de Saúde Mental para equipes ou profissionais da atenção básica. Uma Equipe de Referência em Saúde Mental, sediada ou não em um CAPS, deve ser responsável pelo acompanhamento matricial de 6 até 9 Equipes do PSF ou da atenção básica em geral. Sobretudo nos pequenos municípios, a responsabilidade pelo cuidado aos usuários de Saúde Mental do território deve ser compartilhada entre as Equipes de Referência em Saúde Mental e equipes da Atenção Básica, excluindo a lógica do encaminhamento e visando aumentar a capacidade resolutiva de problemas de saúde pela equipe local. Por sua proximidade com famílias e comunidades, as equipes da atenção básica devem ser consideradas estratégicas para garantir $\mathrm{o}$ acesso e o enfrentamento de agravos vinculados ao uso abusivo de álcool, outras drogas e diversas formas de sofrimento psíquico (Brasil, 2007, p.65).

Para a composição das Equipes de Referência deve-se levar em consideração a existência de outros serviços de saúde mental no território e o tamanho do município. Em municípios que não contam com serviços de saúde mental, por exemplo, a proporção é de uma Equipe de Referência, composta por, no mínimo, um médico psiquiatra (ou generalista com capacitação em saúde mental), dois técnicos de nível superior (psicólogo, terapeuta ocupacional, assistente social, enfermeiro, etc.) e auxiliares de enfermagem, para no mínimo seis e no máximo nove equipes de PSF (Brasil, 2004c).

\footnotetext{
${ }^{3}$ O conceito foi definido por Campos (1999) e, posteriormente, utilizado pelo MS no âmbito da Saúde Mental com especificações que serão citadas neste estudo.
} 
As ações definidas como de responsabilidade das Equipes de Referência compreendem:

- Desenvolver ações conjuntas, priorizando: casos de transtornos mentais severos e persistentes, uso abusivo de álcool e outras drogas, pacientes egressos de internações psiquiátricas, pacientes atendidos nos CAPS, tentativas de suicídio, vítimas de violência doméstica intradomiciliar.

- Discutir casos identificados pelas equipes da Atenção Básica que necessitem de uma ampliação da clínica em relação às questões subjetivas.

- Criar estratégias comuns para abordagem de problemas vinculados à violência, abuso de álcool e outras drogas, estratégias de redução de danos, etc., nos grupos de risco e nas populações em geral.

- Evitar práticas que levem à psiquiatrização e medicalização de situações individuais e sociais, comuns à vida cotidiana.

- Fomentar ações que visem a difusão de uma cultura de assistência não manicomial, diminuindo o preconceito e a segregação com a loucura.

- Desenvolver ações de mobilização de recursos comunitários, buscando construir espaços de reabilitação psicossocial na comunidade, como oficinas comunitárias, destacando a relevância da articulação intersetorial (conselhos tutelares, associações de bairro, grupos de autoajuda etc.).

- Priorizar abordagens coletivas e de grupos como estratégias para atenção em Saúde Mental, que podem ser desenvolvidas nas Unidades de Saúde, bem como na comunidade. 
- Adotar estratégia de redução de danos nos grupos de maior vulnerabilidade, no manejo das situações, envolvendo consumo de álcool e outras drogas. A avaliação da possibilidade de integração dos agentes redutores de dano a essa equipe de apoio matricial.

- Trabalhar o vínculo com as famílias, tomando-as como parceiras no tratamento, buscando constituir redes de apoio e integração (Brasil, 2004c, p. 81).

A Saúde Mental na Atenção Básica configura uma modalidade de atenção ainda em construção (Brasil, 2007). No PSF/Zerbini da região Sudeste é composta por: psicólogos, terapeutas ocupacionais e psiquiatras na proporção de um Técnico de Referência de Saúde Mental (TRSM) para cada quatro ESF.

Essa ESM iniciou suas atividades em 1998 com quatro integrantes e foi ampliada gradativamente à medida que houve a expansão do número de ESF na região, que passou de 15 ESF em 1998 para 42 ESF em 2005.

As ações desenvolvidas pela ESM desse PSF compreendem:

- a realização de reuniões mensais com as ESF, em que se discutem as situações de pessoas com sofrimento mental da área, tanto os casos novos como o andamento das situações acompanhadas. Nessa ocasião também se elabora proposta de intervenção para cada família, definindo quem realizará e como será conduzido o atendimento;

- atendimentos domiciliares (e/ou na Unidade Básica de Saúde (UBS), se necessário) realizados pelo TRSM e com pelo menos um integrante da ESF, em geral, o ACS;

- articulação com outros serviços da comunidade para discussão dos casos e atendimento conjunto; dentre estes os CAPS (Adulto, Adolescente e Álcool e Drogas), Centro de Defesa da Criança e do Adolescente (CEDECA), Conselho Tutelar, Escolas, Espaço Gente Jovem 
(EGJ), Centro de Convivência e Cooperativa (CECCO), Igrejas e Alcoólicos Anônimos (AA);

- capacitações das ESF, em que são abordados temas como: Reforma Psiquiátrica, Saúde Mental, Uso Racional de Psicofármacos ${ }^{4}$, Violência contra Crianças, Redução de Danos, etc. As discussões sobre os casos que ocorrem nas reuniões mensais com as ESF e, principalmente, os atendimentos realizados em conjunto também se caracterizam como oportunidades de qualificação dos profissionais;

- organização de atividades educativas em grupos na UBS ou na comunidade, como oficinas lúdicas para grupos adolescentes, de pais, entre outros;

- participação em reuniões da UBS como: reunião técnica, reunião geral, Conselho Gestor, reunião com representantes da comunidade.

O desenvolvimento das atividades das ESM, no decorrer do tempo, foi confirmando que a estruturação do PSF no tocante aos seus pressupostos, aos objetivos, às atribuições das ESF, à territorialização, entre outros, requer profissionais qualificados, sendo fundamental a oferta de processos de educação continuada, que não seja, como expressa na opinião de Capistrano:

(...) centrada na aquisição de conhecimentos e habilidades técnico-científicas de última geração, pode debruçar-se sobre as questões do trabalho em equipe, do aprendizado mútuo, do relacionamento com a comunidade e da extração de leite das pedras: como buscar obstinadamente melhorar as condições de vida e saúde de grupos sociais que vivem com tão pouco e tão mal (Capistrano, 1999, p. 93).

\footnotetext{
4 "Psicofármacos $=$ medicamentos psiquiátricos utilizados para o tratamento em crise ou manutenção: antipsicóticos, antidepressivos, tranquilizantes, antiepilépticos, estabilizadores do humor" . (Brasil, 2004c)
} 
As ações de saúde mental neste PSF tem a família como foco de atenção e priorizam-se as situações de maior risco para as pessoas.

[São] "exemplos de situações de risco: exclusão social (pacientes egressos de hospital psiquiátrico, pessoas em prisão domiciliar, população em situação de rua, idoso em situação de abandono, crianças e adolescentes em situação de risco pessoal e social etc.); transtornos mentais severos e persistentes (graves); suicídios e tentativas de suicídio em adolescentes e adultos jovens; violência intrafamiliar; problemas clínicos relacionados ao uso e abuso de álcool e outras drogas; abuso e dependência de benzodiazepínicos". (Brasil, 2003, p.4)

Durante os nove anos de trabalho conjunto verificou-se que as respostas simplificadas para estas famílias com pessoas em sofrimento psíquico, que eram internar ou não internar, foram substituídas por propostas de inserir as pessoas nos cuidados de saúde geral da UBS, nos grupos realizados (entre eles a caminhada, artesanato e cozinha natural) e nos serviços de saúde mental da comunidade (CAPS e CECCO). As discussões de casos ou de temas, visitas aos serviços de saúde (entre eles hospitais psiquiátricos), e os atendimentos conjuntos são estratégias que possibilitaram a construção de respostas mais elaboradas e eficazes na atenção em saúde mental.

Os ACS são, na maioria das vezes, aqueles que trazem as situações de sofrimento mental para as discussões com a ESM. Isto porque são procurados pelas famílias que solicitam o agendamento de consulta com um técnico de Saúde Mental ou, durante a VD verificam que algo "não está bem". Sua proximidade das famílias também contribui na elaboração das ações e para a aproximação de outros integrantes do PSF das famílias a serem atendidas. 


\subsection{Os Agentes Comunitários de Saúde}

$\mathrm{Na}$ história de programas de saúde implantados no Brasil, Silva e Dalmaso (2002) identificaram precursores do PACS e do PSF: o Serviço Especial de Saúde Pública (SESP), de 1942 a 1960, a Fundação Serviço Especial de Saúde Pública (FSESP) de 1960 a 1990, e o Programa de Interiorização de Ações de Saúde e Saneamento (PIASS).

A FSESP, por exemplo, funcionou como um 'laboratório' para as propostas do PACS e PSF, já que nesta, as visitadoras sanitárias, desenvolviam ações junto aos indivíduos e famílias, na unidade e na comunidade, sob orientação e supervisão do enfermeiro, sendo cada visitadora responsável por uma determinada área do município.

Já o PIASS, instituído em 1976, na região Nordeste do Brasil - 1a fase e, no Vale do Ribeira, Estado de São Paulo, na 2a fase - Projeto Devale, caracterizou-se pela utilização de pessoal de nível auxiliar, recrutado nas próprias comunidades, como ocorre atualmente com a contratação dos ACS.

O Programa de Agentes Comunitários de Saúde (PACS) foi inicialmente implantado no Estado do Ceará, a partir de 1987.

(...) é proposto em um contexto de emergência social e econômica, de calamidade pública. A ênfase, no primeiro momento, era o programa 'frentes de trabalho', como gerador de emprego e renda (Silva, Dalmaso, 2002, p. 64).

Através de repasse de verbas federais, foram contratadas para este Programa 6.113 pessoas de 118 municípios cearenses entre os anos de 1987 e 1988, ou seja, este primeiro trabalho em ampla escala dos ACS tinha por objetivo primordial a sobrevivência dessas pessoas. Após o 
abrandamento do período de seca foi desativado e o governo do Ceará manteve o Programa Agentes de Saúde em 45 municípios.

Em 1991, o Ministério da Saúde/Fundação Nacional de Saúde (MS/FNS) criou o Programa Nacional de Agentes Comunitários de Saúde (PNACS), tendo em vista os indicadores positivos alcançados pelo PACS cearense. Seu início deu-se no Nordeste e, num segundo momento, chegou à região Norte.

Em 1992, o programa passou a chamar-se Programa de Agentes Comunitários de Saúde (PACS) e as Secretarias Estaduais de Saúde (SES) repassavam recursos para sua implantação.

A partir de 1994, iniciou-se a implantação do PSF no Brasil e neste o ACS foi um dos integrantes das ESF. Suas atribuições no PSF abrangem:

- realizar mapeamento de sua área;

- cadastrar as famílias e atualizar permanentemente esse cadastro;

- identificar indivíduos e famílias expostos a situações de risco;

- identificar áreas de risco;

- orientar as famílias para utilização adequada dos serviços de saúde, encaminhando-as e até agendando consultas, exames e atendimento odontológico, quando necessário;

- realizar ações e atividades, dentro de suas competências, nas áreas prioritárias da Atenção Básica;

- realizar, por meio da visita domiciliar, acompanhamento mensal de todas as famílias sob sua responsabilidade;

- estar sempre bem informado, e informar aos demais membros da equipe sobre a situação das famílias acompanhadas, particularmente aquelas em situações de risco; 
- desenvolver ações de educação e vigilância à saúde, com ênfase na promoção da saúde e na prevenção de doenças;

- promover a educação e a mobilização comunitária, visando desenvolver ações coletivas de saneamento e melhoria do meio ambiente, entre outras;

- traduzir para a ESF a dinâmica social da comunidade, suas necessidades, potencialidades e limites;

- identificar parceiros e recursos existentes na comunidade que possam ser potencializados pelas equipes (Brasil, 2004d, p.78).

O ACS deve ser uma pessoa comunicativa e de liderança em sua comunidade. Funciona como elo entre a equipe e a comunidade.

Está em contato permanente com as famílias, o que facilita o trabalho de vigilância e promoção da saúde, realizado por toda a equipe. É também um elo cultural, que dá mais força ao trabalho educativo, ao unir dois universos culturais distintos: o do saber científico e o do saber popular (Brasil, 2004d, p.78).

Em 10 de julho de 2002 a Lei no 10.507 cria a Profissão de Agente Comunitário de Saúde cujos requisitos para exercê-la são: residir na área de abrangência em que atuar; realizar o curso de Formação de ACS e ter concluído o ensino fundamental (Brasil, 2002c).

A expansão do PSF foi acompanhada da elaboração de estudos, dentre estes há os que tratam do ACS e o modo como vivenciam esta condição de ser trabalhador e integrante da comunidade, o seu acesso às informações dos usuários de sua área e suas atribuições.

Nunes et al (2002) verificou que, se por um lado os ACS sentem-se orgulhosos ao constatar que, com a formação que recebem, seus 
conhecimentos em saúde são diferenciados em relação aos outros indivíduos de sua comunidade, por outro lado, ao compararem esse mesmo conhecimento com o dos outros integrantes da sua ESF, sentem frustração e insatisfação frente à insuficiência da educação que recebem. Este autor relata ainda que, em relação às atribuições do ACS, no tocante à identificação das situações de risco e orientação das pessoas quanto à utilização da UBS, um complicador se faz quase sempre presente, são as "facilitações" para agendar consultas com os profissionais da Unidade Básica de Saúde. Os ACS podem priorizar o atendimento de algumas famílias com quem têm mais proximidade em detrimento de outras.

(...) numa posição estratégica de mediador entre a comunidade e o pessoal de saúde, ele pode funcionar ora como facilitador, ora como empecilho nessa mediação (Nunes 2002, p.1640).

Em relação ao saber, Zancheta et al (2005) e Levy (2004) afirmam que o saber dos ACS transita entre o saber científico e o saber popular. Conhecem os recursos e o funcionamento da comunidade e dividem estas informações com sua equipe. Também atuam como um tradutor para a comunidade de orientações técnicas numa linguagem acessível à população.

Já Fortes e Spinetti (2004) investigaram o fato dos ACS serem da comunidade e o direito à privacidade das informações sobre os usuários. Reconhecem que essa condição possibilita-Ihes o acesso a informações sobre a condição de saúde de integrantes da comunidade antes mesmo da ESF e discutem o limite do acesso dos ACS às informações sobre os usuários da Unidade de Saúde, dado que habitam a mesma comunidade. Os autores consideram que o sigilo das informações dos usuários constitui em obrigação ética de todos os trabalhadores do PSF. 
Em relação ao treinamento dos ACS, Tomaz (2002) destaca as dificuldades quanto à falta de uma delimitação clara em relação às atribuições dos ACS. Estes se vêem envolvidos em qualquer situação ou ação realizada em sua microárea, que pode consistir desde "criança fora da escola" até "limpeza de caixas d'água". Para cada ação nova em que é incluído, o ACS passa por microtreinamentos que nem sempre ocorrem segundo uma seqüência lógica.

A inserção da ESM no PSF/Zerbini também traz atribuições diferentes para o ACS em relação aos demais PSF do Brasil, como, por exemplo, os atendimentos às pessoas em sofrimento mental com os TRSM.

Quanto às capacitações em saúde mental, há aquelas realizadas para todos os funcionários que ingressam nesse PSF, inclusive os ACS e há, ainda, as que ocorrem em cada uma das nove UBS da região Sudeste. São capacitações desenvolvidas pelos TRSM de acordo com sua disponibilidade e das ESF, bem como das demandas destas equipes por temas específicos de saúde mental, como Redução de Danos, Uso Racional de Psicofármacos, etc. Não há, necessariamente, continuidade ou uma seqüência préestabelecida nestas capacitações.

Se este trabalho em conjunto com a ESM pode ser uma atribuição a mais para os ACS, deve-se considerar que conhecer as condições de saúde da população e compartilhar essa informação com sua ESF já é uma de suas tarefas e que, dentre os adoecimentos com os quais os ACS vão se deparar, estão as situações de sofrimento mental. $O$ trabalho conjunto subsidia, então, a assistência às pessoas com sofrimento psíquico que já estão na área, integram as famílias da área de abrangência do PSF, não há uma demanda a mais, mas uma atenção específica para as situações existentes. 
Verificou-se, no entanto, a existência de pessoas com sofrimento mental sem assistência dentre as famílias cadastradas no PSF, ou seja, situações que ou não foram identificadas como sofrimento mental, ou não foram compartilhadas com as ESF e ESM. São situações descobertas por acaso pela observação durante os atendimentos na comunidade, comentário de vizinhos ou familiares, ou através da procura espontânea das pessoas com sofrimento psíquico ou seus familiares por atendimento de psicólogo ou psiquiatras nas UBS.

Dada a importância dos ACS na identificação das situações de adoecimento mental, já que são eles que realizam o cadastro das famílias e têm seu trabalho mais próximo da comunidade do que dos demais integrantes da ESF, possibilitando conhecer demandas que não chegam à UBS espontaneamente, algumas hipóteses foram formuladas a partir da constatação de situações de sofrimento mental sem assistência. Estas hipóteses orientaram a realização do presente estudo:

- as situações de sofrimento mental não são consideradas pelo ACS como agravos à saúde passíveis de intervenção;

- os ACS não possuem clareza de como configuram as situações de sofrimento mental, ou seja, não reconhecem sinais e sintomas de tais situações;

- ao se deparar com famílias com integrantes que apresentam comportamentos "diferentes" sentem receio, medo de se aproximarem das famílias;

- o excesso de trabalho pode levá-los a ocultar as situações de sofrimento mental já que tais famílias poderiam demandar maior número de visitas durante o mês; 
- as capacitações (temáticas e capacitação em serviço ${ }^{5}$ ) não são suficientes para esclarecer formas de identificação de sofrimento mental;

- os ACS têm dificuldades nos encaminhamentos com o técnico de Saúde Mental que é referência de sua equipe;

- tendo vivenciado situações de sofrimento mental em seu meio familiar, os ACS preferem manter distância das situações que os remetem à experiência vivida.

\footnotetext{
${ }^{5}$ Os atendimentos às famílias são realizados pela ESM com integrantes da ESF, geralmente o ACS, ou seja, uma forma de capacitação em serviço.
} 


\section{OBJETIVOS}

- Conhecer as percepções dos ACS relacionados ao sofrimento mental.

- Caracterizar as ações dos ACS frente à identificação de pessoas em situações de sofrimento mental. 


\section{METODOLOGIA}

\subsection{Referencial Teórico}

A proposta de atenção à saúde dirigida ao sujeito em sofrimento, considerando seus aspectos biopsicossociais e não um corpo doente, ou a "doença", se apresenta tanto nas estratégias do Programa Saúde da Família, quanto da Reforma Psiquiátrica Brasileira e da Vulnerabilidade.

No PSF, a reorientação do modelo assistencial à saúde responde "a uma nova concepção de saúde, não mais centrada somente na assistência à doença ${ }^{6}$ mas, sobretudo, na promoção da qualidade de vida e intervenção nos fatores que a colocam em risco" (Brasil, 2000, p. 2). Para tanto, as ações das ESF devem ir além de estabelecer o perfil epidemiológico da população e, incluem "conhecer os fatores (sociais, políticos, econômicos, ambientais, culturais, individuais) que determinam a qualidade de vida da comunidade adscrita" (Brasil, 2004d). Os elementos orgânicos (biológicos) também devem ser considerados, somados aos subjetivos e sociais, tanto no diagnóstico quanto na terapêutica (Campinas, 2001).

No âmbito da Reforma Psiquiátrica Brasileira, o alvo da atenção também não é a doença, mas o sujeito em sofrimento mental. Esta mudança, da atenção à 'doença mental' para o 'sujeito em sofrimento mental', foi uma das críticas à psiquiatria tradicional iniciadas por Franco Basaglia e continuada pelo movimento da psiquiatria democrática italiana. $\mathrm{O}$ conceito de doença mental, produzido pela psiquiatria, no entendimento de Basaglia, "reduziu a complexa experiência da loucura aos limites do campo médico" (Amarante, 2003, p.67).

\footnotetext{
${ }^{6}$ Grifos meus.
} 
É necessário, então, colocar a doença entre parênteses, ou seja, não se limitar a 'doença', algo no corpo do indivíduo, mas ocupar-se da 'existência-sofrimento' das pessoas e sua relação com o corpo social (Rotelli, Leonardis, Mauri, 1990b).

Dessa maneira, as ações terapêuticas não devem ter como objetivo a 'cura' mas "a produção de vida, de sentido, de sociabilidade, a utilização das formas (dos espaços coletivos) de convivência dispersa". (Rotelli, Leonardis, Mauri, 1990b, p.30) e devem ser desenvolvidas no território onde as pessoas vivem.

Rotelli (1990a) denomina de desinstitucionalização ao processo de questionamentos quanto ao modo como a psiquiatria se relaciona com a "doença":

A desinstitucionalização torna-se assim um processo, a um só tempo, de desconstrução dos saberes e práticas psiquiátricas - expresso principalmente nos princípios do colocar entre parênteses a doença mental, o que permite a identificação e a desmontagem do duplo da doença mental, e no trabalho com o sujeito concreto, encortinado pelo conceito de doença-, e de invenção prático-teórica de novas formas de lidar, não mais com a doença, mas com o sujeito doente (Amarante, 1996, p. 100).

Quanto ao conceito de Vulnerabilidade, que extrapolou o campo da aids e "é aplicável, rigorosamente, a qualquer dano ou condição de interesse para a saúde pública" (Ayres et al, 2003, p.117), pode-se dizer que o adoecimento das pessoas decorre de aspectos relacionados a três dimensões: individual (conhecimentos, atitudes, crenças, etc.), social (acesso aos meios de comunicação, escolarização, disponibilidade de recursos materiais, etc.) e programáticos/institucionais (quanto aos serviços, 
em especial os de saúde, disponíveis e que propiciem que os sujeitos superem sua condição de vulnerabilidade) (Ayres et al, 2006).

A promoção de saúde e exercício da cidadania é outro aspecto comum destas estratégias. No âmbito do PSF se propõe o estímulo as discussões dos direitos e incentivo da população na participação do controle social (Brasil, 1997). Em relação à saúde mental, deve-se buscar "a reconstrução da cidadania plena do paciente psiquiátrico" (Saraceno, 1999) e, no âmbito da Vulnerabilidade, cujo conceito é oriundo da área dos Direitos Humanos, as práticas e a construção de cidadania são indissociáveis das ações de prevenção e cuidado (Ayres et al., 2006). Para se efetivar essa reconstrução, considerando os três contextos mencionados, é necessário que se estabeleçam alianças com outros serviços de saúde e equipamentos sociais, envolvendo, entre outros, as áreas da educação, habitação, ou seja, o trabalho intersetorial é imprescindível.

Um outro aspecto a se considerar relacionado, em especial, as estratégias do PSF e Reforma Psiquiátrica diz respeito a noção de "território" e de "tomada de responsabilidade". Território aqui definido como:

(...) não apenas da região, no sentido geográfico tradicional, ou do lugar de moradia das pessoas, mas do conjunto de referências subjetivas, sociais e políticas que formam 0 cotidiano de vida e a inserção dos sujeitos no meio social (Amarante, 2003, p. 74).

Tanto no PSF como na Reforma Psiquiátrica os serviços devem se responsabilizar pelo sujeito da área de abrangência "com todo alcance social conectado ao estado de sofrimento" (Dell'Acqua et al, 1991, p. 63) e prestar atenção integral a sua saúde. Esta atenção modifica a lógica do encaminhamento, pois mesmo que os sujeitos em sofrimento necessitem de outro nível de atenção, é no território, na sua equipe que tem uma referência de atendimento. 
Assim, foi na perspectiva de saúde ampliada que visa a promoção de cidadania, com equipes responsáveis por um território adscrito e estabelecendo ações intersetoriais que se desenvolveu este estudo.

\subsection{Sujeitos}

A população do estudo foi constituída por doze ACS que trabalham nas UBS do PSF/Zerbini da região Sudeste, com base nos seguintes critérios de inclusão: trabalhar há mais de um ano no PSF; concordar espontaneamente na participação da entrevista e não ter desenvolvido nenhuma atividade de trabalho anterior a este estudo com a pesquisadora.

\subsection{Local do estudo}

O estudo foi realizado em cinco UBS do PSF/Zerbini, localizadas no distrito de Vila Prudente/Sapopemba, região sudeste de São Paulo (ANEXO I).

Vila Prudente/Sapopemba é a segunda mais populosa subprefeitura do município de São Paulo com 523.676 habitantes distribuídos numa área de $33,3 \mathrm{~km}^{2}$ (São Paulo, 2005). É formada pelos bairros de Vila Prudente, Parque São Lucas e Sapopemba.

O nascimento do bairro de Vila Prudente foi notícia do jornal O Estado de São Paulo em 7 de outubro de 1890 e seu nome é uma homenagem ao governador do Estado Prudente de Moraes. Neste mesmo ano instalou-se aprimeira indústria na região, pertencente aos irmãos Falchi (imigrantes italianos) que foi seguida por outras. No início do século XX Vila Prudente transformou-se em "uma grande vila fabril" (SP, 2005) o que motivou o povoamento local. "Junto com o desenvolvimento e a urbanização, vieram os problemas sociais. Em 1940, surge a primeira favela de Vila Prudente (...)" (SP, 2005). Com o passar dos anos as indústrias perderam força, com o 
fechamento de algumas ou transferência para outros locais, o bairro assim tornou-se uma área de comércio e serviços.

Já o Parque São Lucas, formado de terras alagadas, só em 1950 apresentou um significativo crescimento econômico e encontrou "no comércio sua vocação regional" (SP, 2005).

Com a extensão de $13,5 \mathrm{~km}^{2}$ e 282.239 habitantes, Sapopemba (nome de uma árvore da Amazônia de raízes de até dois metros de altura), apresentava terras vermelhas próprias para a agricultura e produção de telhas e tijolos, teve seu povoamento iniciado por volta de 1910 .

Santos, Kretzer e Matos (2004) destacam dois fatos na história do bairro: "a chegada da imagem de Nossa Senhora de Fátima, encomendada pelos portugueses e vinda de Portugal em 1931 [e] a construção da Adutora do Rio Claro" concluída em 1937 e responsável, atualmente, pelo abastecimento de água para mais de um milhão de pessoas.

O local é fruto, ainda, de "várias ocupações, conseqüência da luta pela sobrevivência de um grande número de migrantes, principalmente do Nordeste, que chegaram a São Paulo nas décadas de 1960 e 1970, em busca de melhores condições de vida" (Santos, Kretzer e Matos, 2004).

No distrito de Vila Prudente/Sapopemba há 50 favelas onde habitam 59.608 pessoas, ou seja, $11,38 \%$ da população total deste distrito. Indicadores sócio-econômicos apontam que $53,07 \%$ dos chefes de família ganham até 5 salários mínimos e 10, 62\% não tem rendimentos.

No triênio 2000/2002, 38,7\% dos óbitos de homens entre 10 e 49 anos deste distrito tiveram como causa as agressões e homicídios. Entre as mulheres, na mesma faixa etária, as agressões e homicídios causaram 9,4\% dos óbitos (Fundação SEADE, c2007). 
Quanto aos equipamentos culturais, a Fundação SEADE (c2007) registra 10 salas de cinema e 2 bibliotecas municipais neste distrito e nenhuma ocorrência de salas de teatro, casas de cultura, centros culturais, museus e espaços e oficinas culturais.

Há um hospital municipal e dois estaduais que disponibilizam 219 leitos para a população local e a atenção a saúde ainda é desenvolvida por 22 Unidades Básicas de Saúde (SMS/PMSP, 2005b). A atenção em saúde mental é realizada pela ESM do PSF/Zerbini, por quatro Centros de Atenção Psicossocial (um para atender crianças e adolescentes, dois para atender adultos e um para tratamento de dependentes de álcool e outras drogas), um Centro de Convivência e Cooperativa (CECCO) e emergência psiquiátrica em um hospital geral.

As UBS do PSF/Zerbini atendem a $29,7 \%$ da população do distrito de Vila Prudente/Sapopemba, ou seja, 155.454 pessoas, em nove unidades com 42 ESF: Jardim Guairacá, Reunidas I, Iguaçu, Sinhá, Juta I, Juta II, Vila Renato, Pastoral e Parque Santa Madalena. Também integram este PSF uma Casa de Parto e um Ambulatório de Especialidades, e, além da ESM, desenvolvem trabalho junto as ESF uma Equipe de Saúde do Deficiente (composta por fonoaudiólogos, terapeutas ocupacionais e fisioterapeutas, que são referência para as nove unidades) e Equipes de Saúde Bucal (uma ou mais equipes em cada UBS, compostas por cirurgião dentista, técnico em higiene dental e atendente de consultório dentário).

\subsection{Coleta de Dados}

\subsubsection{Procedimentos ético-legais}

A pesquisa foi encaminhada ao Comitê de Ética em Pesquisas da Secretaria Municipal de Saúde do Município de São Paulo - CEP/SMS que 
analisou e aprovou-a de acordo com a Resolução 196/96 - Parecer nº 089/06/CEP/SMS de 04 maio de 2006.

A coleta de dados foi precedida da apresentação pela pesquisadora aos ACS e leitura do Termo de Consentimento Livre e Esclarecido (ANEXO II) pelos Agentes e, assinado por cada entrevistado após esclarecerem suas dúvidas quanto a realização da entrevista.

\subsubsection{Entrevistas}

Os ACS de cada UBS foram convidados a participar de uma reunião na qual a pesquisadora apresentou o projeto de pesquisa, seus objetivos e procedimentos de coleta de dados. Nesta ocasião os ACS tiveram oportunidade de esclarecerem dúvidas sobre o estudo e, com aqueles que manifestaram interesse em participar da entrevista, foi agendada uma data para sua realização.

A entrevista foi individual nas datas e horários previamente agendados, em sala da UBS, preparada com antecedência, de forma a garantir o sigilo das informações. Foram gravadas com o consentimento dos ACS e transcritas pela pesquisadora.

Utilizou-se a entrevista semi-estruturada com a utilização de um roteiro de orientação (Anexo III). Outras perguntas foram formuladas no decorrer da entrevista com o intuito de aprofundar as informações almejadas (Minayo, 1993).

A coleta de dados encerrou-se quando o conteúdo dos depoimentos tornou-se repetitivo, ou seja, quando não surgiram "mais conteúdos novos a respeito do objeto de representação estudado" (Souza Filho, 1995, p.117). 


\subsubsection{Análise dos dados}

De acordo com a análise temática proposta por Minayo (1993) realizou-se as etapas de leitura atenta e exaustiva da transcrição das entrevistas realizadas, identificação de falas significativas, localização de pontos de saturação e organização do material em núcleos temáticos de acordo com a pertinência e representatividade dos assuntos expressos.

Para a análise das situações identificadas como adoecimento mental pelos ACS, utilizou-se de uma versão da Classificação Internacional das Doenças elaborada pela OMS "para o profissional ao nível de cuidados primários" chamada Diretrizes Diagnósticas e de Tratamento para Transtornos Mentais em Cuidados Primários (OMS, 1998, p.VII). Trata-se de uma versão concisa e de fácil manejo que orienta o diagnóstico e tratamento das situações de sofrimento mental na atenção básica à saúde. 


\section{RESULTADOS E DISCUSSÃO}

\subsection{Caracterização da população estudada}

A análise de algumas características do grupo estudado revelou que $100 \%$ do grupo é do sexo feminino, com idade entre 25 e 48 anos e que $75 \%$ deles são casados. Dois ACS residem no bairro onde trabalham há cinco anos sendo que, a maioria deles, mais de $80 \%$, é morador do local há nove anos ou mais, o que pode lhes permitir um conhecimento amplo dos moradores da comunidade, dos recursos e da história do local. Embora seja exigido o ensino fundamental para contratação dos ACS, a maioria deles, mais de $80 \%$ concluiu o $2^{\circ}$ grau. Aproximadamente $70 \%$ dos ACS referiram ter participado de alguma capacitação em saúde mental no PSF, o que pode explicar a compreensão que possuem de sofrimento mental, bem como sua atuação na assistência em saúde mental deste PSF.

Gráfico 1: Distribuição por sexo

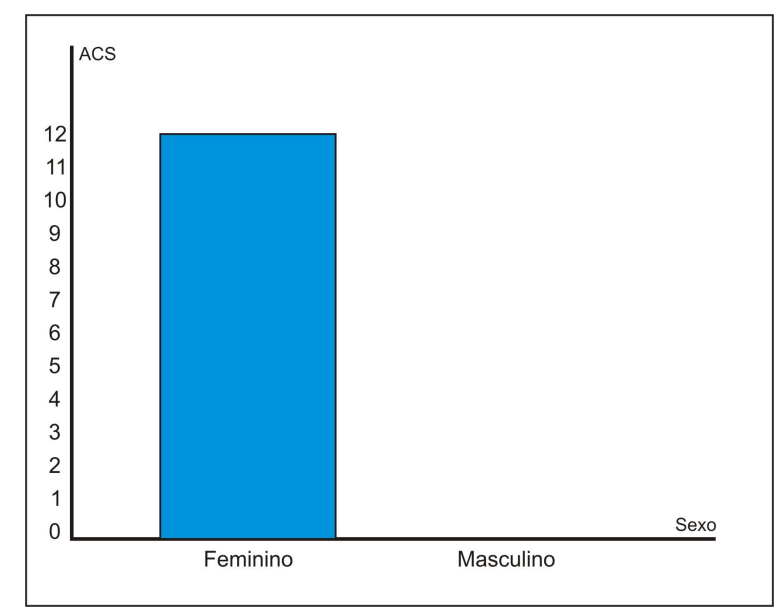


Gráfico 2: Distribuição por faixa etária

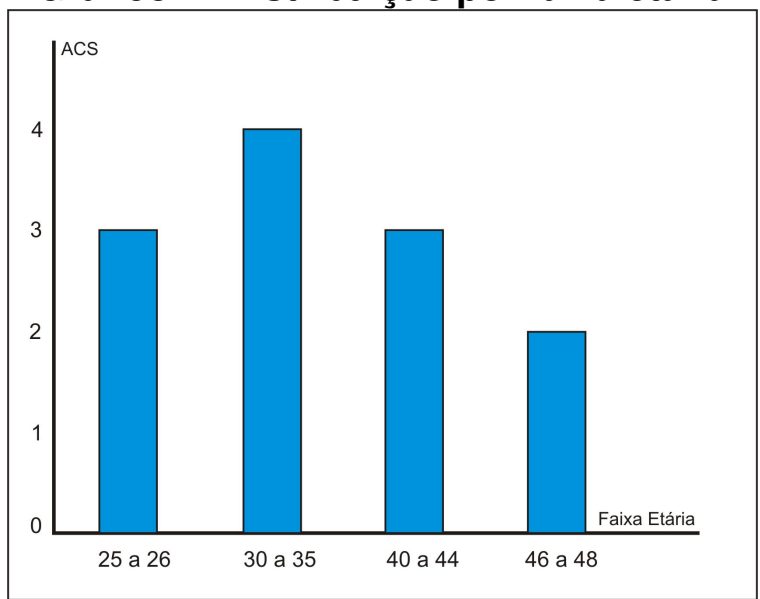

Gráfico 3: Distribuição por escolaridade

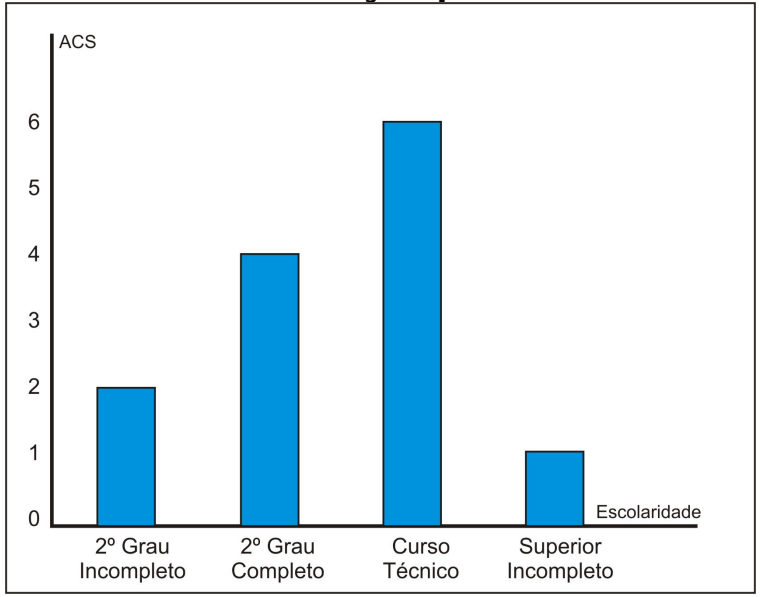

Gráfico 4: Distribuição por estado marital

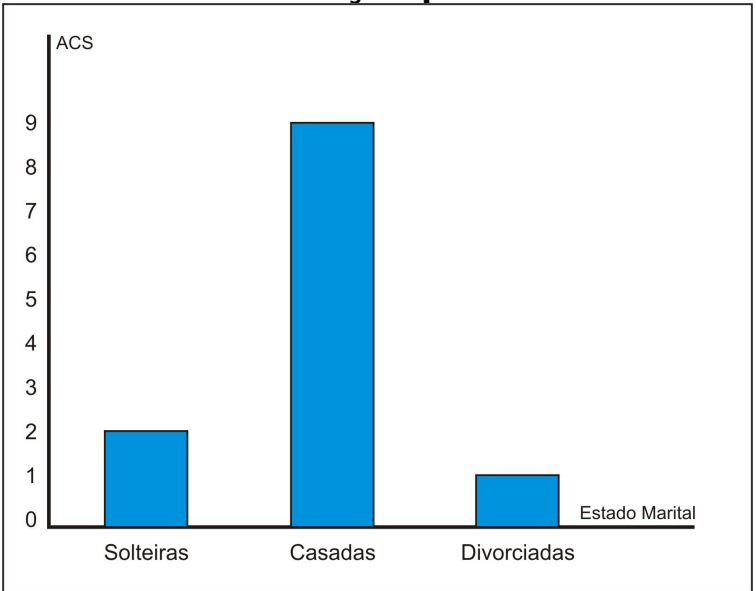


Gráfico 5: Distribuição por tempo de moradia no bairro

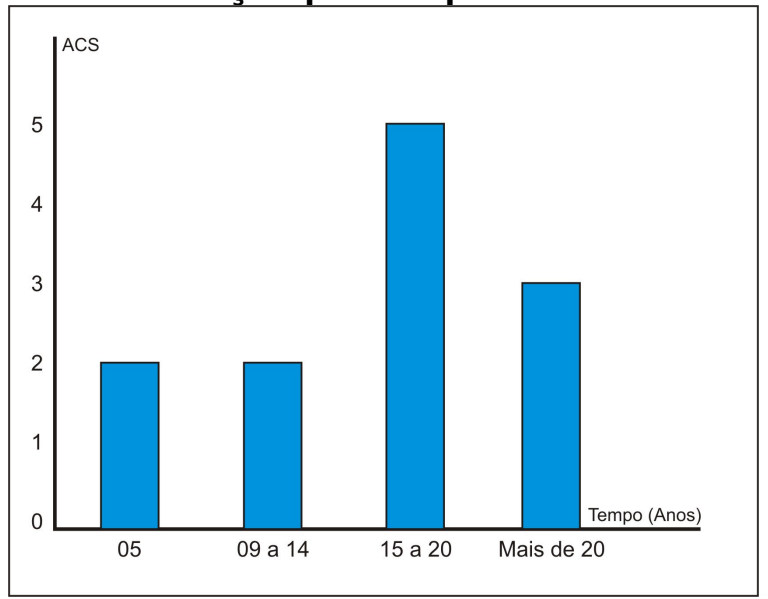

Gráfico 6: Distribuição por tempo na função de ACS

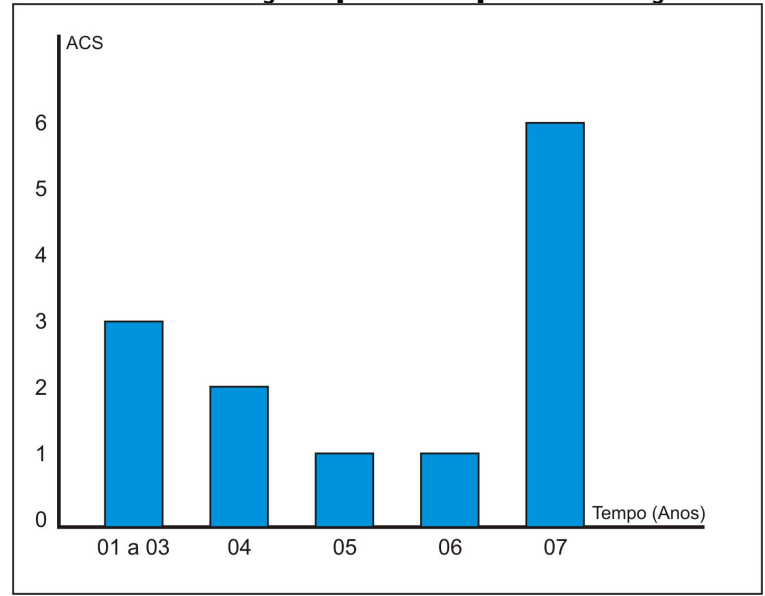

Gráfico 8: Distribuição por capacitação em Saúde Mental

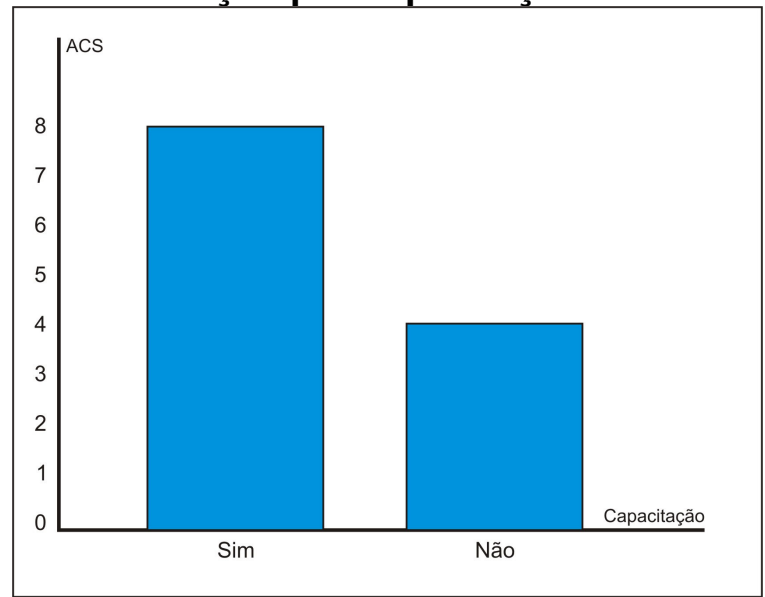




\subsection{Núcleos temáticos}

A partir da análise temática das entrevistas realizadas verificaram-se dois núcleos temáticos a compreensão de sofrimento mental dos ACS e as condutas destes ACS na atenção em Saúde Mental no território da unidade de saúde do PSF.

O primeiro núcleo abrangeu os dois modos como os ACS identificam as pessoas com sofrimento mental e as causas deste sofrimento.

O segundo núcleo, das condutas de saúde dos ACS na atenção à Saúde Mental no PSF, compreende as ações e tratamentos realizados e ou orientados pelos ACS e os elementos que facilitam ou dificultam essa atenção.

TEMA 1. A compreensão de sofrimento mental: a identificação de casos e suas causas.

Há duas formas de os sofrimentos psíquicos chegarem ao conhecimento dos ACS: a primeira se dá por meio de registros ou de solicitações por parte dos usuários, de familiares ou de outros serviços, de alguma ação no âmbito da Saúde Mental; e a segunda ocorre pela detecção do próprio ACS, pela sua observação.

Destaca-se a relevância da identificação realizada pelos ACS pela observação, pois são situações de sofrimento mental que poderiam não ser identificadas pelos serviços de saúde ou serem diagnosticadas tardiamente, retardando as intervenções. Sobre a importância na rapidez da intervenção em situações de sofrimento mental, a OMS esclarece que: 
a intervenção precoce é fundamental no bloqueio do progresso rumo a uma doença plenamente instalada, no controle dos sintomas e na melhoria dos resultados. Quanto mais depressa for instituído um curso de tratamento, melhor será a prognose (OMS, 2001, p.86).

A identificação do sofrimento mental é o primeiro passo para o planejamento e implementação de ações com vistas à promoção de Saúde Mental de usuários e familiares.

\section{Categoria 1.1 Identificação através dos registros, de solicitação dos moradores e de outros serviços.}

O primeiro contato dos ACS, no exercício de sua profissão, com as famílias moradoras de sua área de abrangência e, por conseguinte, com as pessoas em sofrimento mental, se dá durante o cadastro das mesmas. Nessa situação os agentes preenchem uma ficha com informações dos moradores e do domicílio de sua área. As informações são inseridas em um banco de dados do Sistema de Informações da Atenção Básica (SIAB), proporcionando "uma descrição físico-sanitária da população acompanhada" (Brasil, 1998a, p.5). Um dos campos para preenchimento desta ficha é o de doença ou condição referida, ou seja, agravos à saúde mencionados pelo informante da família. Os problemas mentais são notificados com os códigos ALC para alcoolismo e DME para distúrbio mental, mas não há no manual do SIAB definição destes termos (Brasil, 1998a). Diferentemente dos outros agravos, não é possível registrar o item DME nesse banco, segundo os auxiliares administrativos responsáveis pela "alimentação" do banco de dados do SIAB nas UBS em que o estudo foi realizado.

Levando-se em consideração que o conhecimento da magnitude do adoecimento mental é imprescindível na organização de políticas públicas e 
planejamento das ações (Saraceno, Asioli, Tognoni, 1997), é inegável que a inexistência de informações adequadas, a incompletude e a nãoconfiabilidade dos registros dificultam o dimensionamento da situação epidemiológica desse adoecimento nas áreas de abrangência do PSF. Para modificar essa inadequação das informações, uma das providências seria a melhoria no registro sobre as doenças mentais no SIAB conforme recomendado pelo Ministério da Saúde (Brasil, 2004c; Antunes, Pereira, 2003).

A partir de 2005, os indicadores de saúde mental passaram a fazer parte do elenco de indicadores da atenção básica, embora a mudança no Sistema de Informações da Atenção Básica (SIAB) ainda não tenha entrado em vigor" (Brasil, 2007, p. 22).

Os ACS reconhecem esta subnotificação e referem que os dados em relação ao sofrimento mental se perdem, não são computados, dificultando que sua magnitude no território ganhe visibilidade.

[...] quando [a informação sobre as pessoas com sofrimento mental] vai para o SIAB desaparece, ela é jogada como deficiente físico, então a gente não tem um número para mostrar. ACS6

Outra forma de as informações sobre o sofrimento mental da população tornarem-se conhecidas pelos ACS se dá quando os usuários solicitam que estes ACS viabilizem atendimento com psicólogo ou psiquiatra. Os usuários apresentam queixas inespecíficas como "não se sentirem bem" ou relatam terem abandonado o tratamento em outro serviço de saúde, público ou privado, e sentirem a necessidade de retomar o mesmo. 
[...] a pessoa mesma falava que precisava passar no psicólogo, "acho que eu tenho algum problema", então eles mesmos falam que notam que têm alguma coisa errada. Alguma coisa que eles não conseguem controlar. ACS 10

[...] A família que me procurou, fazia muito tempo que ela fazia tratamento, mas ela sempre abandona, ela pára o tratamento e ela estava em crise [...] ACS 6

O tratamento interrompido nesta situação a que os ACS se referem é o tratamento medicamentoso. Em algumas situações o usuário, ou seu familiar, apresenta receita de psicofármacos já utilizados ou um encaminhamento de outro serviço de saúde para agendamento de consulta com profissionais da ESM.

Há ainda situações em que familiares, amigos e vizinhos percebem alterações no comportamento de uma pessoa e procuram os ACS, especialmente se a pessoa não quer assistência à saúde ou tem um comportamento considerado anormal pela comunidade, sendo rotulada de "louca".

[...] O pessoal da vila, da rua, me falou que ela era meio louca, ela era chamada de louca. ACS 3

As solicitações ocorrem nas VD ou em condições que extrapolam 0 horário e local de trabalho dos ACS.

[...] Já tive pessoas de encontrar no mercado e ela começar a chorar, essa foi a primeira vez que me deparei com uma situação assim. Eu estava no mercado, nem estava trabalhando. Foi bom porque eu não sabia do caso. Pior que 
eu estava com meu marido. Pedi pra ele dar licença um pouco porque a pessoa com quem me deparei ali acaba sendo um amigo. Você entra na casa, ganha confiança, então ela me abordou, começou a falar, falar, começou a chorar, estava em crise. Falou que estava depressiva, que precisava de ajuda, que estava desempregada, que não agüentava mais [...] ACS 8

Embora não seja o foco de investigação deste estudo, chama a atenção o fato do ACS ver-se impelido a responder estas solicitações no supermercado e em companhia de familiar, ou seja, em condições inadequadas, fora de seu horário e local de trabalho, para o propósito de ouvir alguém "em crise". O ACS parece, ainda, não ter claro a relação que estabelece com os usuários que, no exemplo acima, é considerado "um amigo"já que o visita e conhece-o intimamente.

Martines (2005) investigou o processo de sofrimento no trabalho dos ACS (no mesmo território onde foram realizadas as entrevistas do presente estudo). Observou as dificuldades de os ACS lidarem com os limites da vida pessoal e o vínculo estabelecido com a comunidade e as conseqüências negativas de um comportamento ilimitado, gerando sofrimento para esses ACS. Por um lado, o sentimento de onipotência, caracterizado em dever de dar respostas para todas as solicitações e, em contrapartida, a angústia da impotência ao se deparar com seus limites. Sugere, assim, que esta aproximação seja repensada.

O vínculo precisa urgentemente ser revisto, para ser apreendido como um imprescindível instrumental, a auxiliar na consolidação do compromisso com a comunidade e não como uma "sina" (Martines, 2005, p.98). 
O desconhecimento do diagnóstico de alguns usuários causa surpresa no ACS que, devido a sua atuação na UBS, tem acesso a informações que não teria fora da mesma, ou seja, poderia nem perceber o sofrimento psíquico de uma pessoa, pois seus comportamentos não correspondem a sua representação de sofrimento mental,

[...] é uma pessoa muito legal, que nem parece que tem esse tipo de problema. (...) Ela cuida da casa dela normal, ela fica normal, eu só sei porque eu trabalho na saúde, senão eu nem ia saber que ela tem esse problema. ACS 11

A solicitação de atualização de receitas médicas para compra de certos tipos de medicação e a referência da utilização desta no preenchimento de ficha de cadastro das famílias possibilita que os ACS identifiquem a pessoa como portadora de sofrimento mental ao reconhecerem que os tais medicamentos são utilizados no tratamento desses problemas.

[...] Quando ela diz que toma uma medicação controlada, faixa preta ${ }^{7}$, já imagino que seja por algum problema mental. ACS 5

[...] Até então eu desconhecia totalmente que ela tinha um filho com esquizofrenia, sempre esteve tudo bem, nunca vi o rapaz lá no quintal, parece até que escondem um pouco o paciente da vista das pessoas mais próximas. Aí vem ela e pergunta: "Como é que faz para pegar os medicamentos?" Quando você lê os medicamentos, você sabe que o doutor manda trocar, que é um medicamento controlado, que precisa de um acompanhamento (...) É um nome estranho,

\footnotetext{
${ }^{7}$ Faixa preta é uma referência a faixa horizontal, de cor preta, nas embalagens dos psicofármacos que podem causar dependência (Barros, Ferigolo, Hortiz, 1999).
} 
da família do Haldol ${ }^{\beta}$. Aí começo a perguntar, a fazer uma sondagem, mas quem toma esse medicamento? $O$ que aconteceu? ACS 2

Em seguida será descrita a identificação de situações de sofrimento mental observadas pelos ACS na atenção às famílias de sua área.

\section{Categoria 1.2 Identificação através da convivência e observação dos moradores da área.}

A riqueza dos resultados obtidos nas entrevistas realizadas com os ACS foi surpreendente ao se verificar o envolvimento dos mesmos com situações de sofrimento mental. Os ACS estabelecem uma relação de proximidade com as famílias, observam-nas, estabelecem diálogos e assim identificam pessoas com sofrimento mental.

Antes de descrever o que os ACS identificam como sofrimento mental, a análise das entrevistas permitiu que se conhecesse o que estes ACS consideram como "comportamento normal" das pessoas de sua área que são: trabalhar, realizar atividades, socializar-se, alimentar-se regularmente e cuidar da higiene pessoal e da moradia.

[...] a pessoa tinha uma vida normal, se socializava com as pessoas, saía, trabalhava [...] . ACS 5

[...] uma pessoa normal tem fome todos os dias de tomar café da manhã, almoçar, tomar café da tarde e jantar. ACS8

\footnotetext{
${ }^{8}$ Nome comercial do psicofármaco haloperidol.
} 
Além desse "comportamento esperado", os ACS referem conhecer os hábitos e o modo de ser dos usuários de sua área que são também seus vizinhos, estes recebem sua VD periodicamente. Conhecem o "normal" de cada pessoa e a modificação de comportamento e dos hábitos dos usuários constitui a primeira forma pela qual identificam que algo pode não estar bem.

[...] quando alguma coisa foge da rotina da pessoa (...) fico mais alerta. Teve uma mudança do que era. ACS 7

[...] Eu conheço o usuário, conheço também quando ele está diferente. Porque sei como ele é no dia-a-dia, porque vou todo mês lá. ACS 8

[...] São pessoas que antigamente falavam muito, me procuravam, solicitavam o posto vinham aqui e por nada, de repente, sumiram e deixaram de circular ali perto de onde eles circulam, deixei de ver. Começa a preocupar porque a pessoa não era assim [...]. ACS 1

Não se trata de uma mudança pontual, de um dia, uma reação a algum fato isolado mas, é algo que é observado por um período de tempo.

[...] Uma pessoa que faz isso num dia e no outro a pessoa melhora, você esquece, você acha que ela não estava bem naquele dia; mas isso foi se estendendo por meses. ACS 1

Segundo a OMS

(...) uma incidência de comportamento anormal ou um curto período de anormalidade do estado afetivo não significa em 
si mesmo a presença de distúrbio mental ou de comportamento. Para serem categorizadas como transtornos, é preciso que essas anormalidades sejam sustentadas ou recorrentes e que resultem em certa deterioração ou perturbação do funcionamento pessoal em uma ou mais esferas da vida (OMS, 2001, p.47).

A apresentação de comportamentos estranhos, exagerados e falas sem sentido dos usuários de sua área constituem uma outra forma pela qual os ACS identificam pessoas com sofrimento mental.

Um desses "comportamentos estranhos" observados ocorre pela utilização de psicofármacos. Esta medicação pode causar efeitos colaterais e reações adversas nas pessoas devido a dosagens excessivas ou hipersensibilidade (Saraceno, Asioli, Tognoni, 1997). A dificuldade de movimentação é um desses efeitos observados pelos ACS que concluem tratar-se de uma pessoa em tratamento com psicofármacos.

[...] Vi que ela anda durinha, durinha, que nem um robozinho (...) depois entendi o que era [efeito colateral do uso de psicofármaco] porque a filha dela falou que ela toma direto esse remédio, esse remédio ele impregna. ACS 4

Ao serem questionados quanto às características de pessoas com sofrimento mental, ou seja, o que as pessoas apresentam para que considerem que tem um problema mental, os ACS citaram comportamentos que configuram os aspectos diagnósticos descritos pela Classificação Internacional das Doenças (CID-10). A CID-10 (OMS, 1998) é "um sistema de classificação mais simples e útil na prática clínica” (Saraceno, Asioli, Tognoni,1997, p.16) e, embora os ACS não tenham clareza sobre o nome 
de um determinado adoecimento mental (o que não é de sua competência), sabem tratar-se de um adoecimento desta natureza.

[...] A esquizofrenia eu não consigo identificar, eu consigo quando a pessoa fala que tem esquizofrenia. Agora quando eu vejo uma pessoa que tenha esquizofrenia eu penso que é uma doença mental [...]. ACS 5

Dentre os adoecimentos mentais descritos na CID 10, os ACS relataram características dos seguintes ${ }^{9}$ : Demência; Transtornos por uso de álcool; Transtorno por uso de drogas; Transtornos psicóticos crônicos; Transtornos psicóticos agudos; Transtorno bipolar; Depressão; Transtornos fóbicos; Queixas somáticas inexplicadas, Retardo Mental e Transtorno obsessivo-compulsivo $^{10}$.

Os ACS citam situações em que o usuário apresenta problemas relacionados à memória, "déficit de memória recente" (OMS, 1998, p. 18), que é uma das características da Demência.

[...] (a pessoa) começava a falar coisas só do passado, as coisas que ela fazia ontem ela não lembrava, se ela almoçasse, ela não lembrava que almoçou. ACS 4

Quanto aos Transtornos por uso de álcool e drogas, decorrentes de seu uso indevido, os ACS relatam que a maior ocorrência se dá entre os adolescentes. Dentre as características relacionadas a este transtorno estão

\footnotetext{
${ }^{9}$ Os outros transtornos abordados são: Delirium; Transtornos por uso de tabaco; Transtorno de pânico; Ansiedade generalizada; Ansiedade e depressão mistas, Transtorno de ajustamento, Transtorno dissociativo (conversivo); Neurastenia, Transtornos alimentares, Problemas de sono, Transtornos sexuais, Retardo mental, Transtorno hipercinético (déficit de atenção), Transtorno de conduta, Enurese, Transtornos de perda, Transtorno mental, sem outra especificação. (OMS, 1998 - p.17)

${ }^{10} \mathrm{O}$ Transtorno obsessivo-compulsivo não é descrito na versão da CID 10 para a atenção primária mas na versão completa.
} 
discutidos na CID 10 os sintomas de abstinência de álcool e conseqüências como "problemas legais e sociais devido ao uso de drogas (problemas conjugais, faltas ao trabalho)" (OMS, 1998, p.24). Os relatos abaixo ilustram situações em que tais sintomas e problemas foram constatados pelos ACS:

[...] quando fica uma semana sem beber, ela começa a ver coisas, começa uma tremedeira, dá muita ânsia de vômito nela, ela fica sem comer, ela fica num mal estar feio mesmo.

\section{ACS 7}

[...] ele está sentindo a necessidade de lutar contra as drogas, ele tem ficado na rua, ele perdeu todo o contato com família, tem três filhos que ele abandonou e ele era um contador, hoje é um morador de rua, ele tem causado um sofrimento muito grande pra ele [...] ACS 5

Os ACS descrevem com detalhes os sintomas dos Transtornos psicóticos crônicos e agudos ${ }^{11}$. Relacionam todos os aspectos diagnósticos citados na CID 10 para descrever estas situações de sofrimento mental de sua área conforme as descrições a seguir ${ }^{12}$ :

No caso de "isolamento social":

[...] Ele parava, não falava com ninguém, ficava com os olhos parados e isso foi aumentando, aumentando, ao ponto dele não sair mais de casa, ficava assim parado. ACS 5

\footnotetext{
${ }^{11}$ Optou-se por agrupar as citações relacionadas aos transtornos psicóticos crônicos e agudos pela semelhança entre seus aspectos diagnósticos sendo sua diferenciação está relacionada com o tempo de sua ocorrência, ou seja, as situações agudas relacionam-se a episódios recentes e os crônicos a persistência dos aspectos acima descritos (OMS, 1998, p.28 a 31).

${ }^{12}$ Todos os aspectos diagnósticos relacionados (entre aspas em itálico) são citações literais da versão do CID 10 aqui utilizada (OMS, 1998, p. 28 a 31).
} 
Em relação a "pouca motivação interesse, autonegligência":

[...] Ela ficou quase dois meses, três meses, sentada num canto, parecia que aquela mulher não tinha alma, ficava ali sentada, não comia, não bebia, não tomava banho, não ia no banheiro, não fazia nada.ACS 3

O "distúrbio do pensamento (evidente pela fala estranha ou incoerente)" também é observado:

[...] ela não fala coisa com nada, ela inventa que tem o lado esquerdo que está perturbando ela. ACS 7

Quanto a "agitação ou inquietação", dizem os ACS:

[...] Pessoa que não conversa, ou quando conversa, não diz coisa com coisa, que tem movimentos de não ficar parada num lugar, fica andando pra lá e pra cá. Não tem um entendimento claro das coisas. ACS 5

No caso de "comportamento bizarro":

[...] Eu tinha uma que andava na rua, todo lixo que ela via ela pegava e colocava no corpo dela, tudo que ela via ela usava: três, quatro, cinco blusa, três calças, aí com o tempo ela foi melhorando (...),ela some andando na rua, passava dias fora. ACS 3 
As "alucinações (percepções falsas ou imaginadas, p. ex. ouvir vozes)" também são exemplificadas:

[...] teve um problema de começar a ouvir vozes, dizer que alguém ia matar ele, que o pai dele tinha falecido e estava chamando ele, que ele precisava ir com o pai só que ele não queria ir. E ele rezava para o pai, para o pai ficar em paz lá, porque ele não queria ir. ACS 1

Quanto aos "delírios" definidos como "(crenças firmes que são claramente falsas, p. ex., o paciente está relacionado com a realeza, recebe mensagens da televisão, está sendo seguido ou perseguido)", dizem os ACS:

[...] Tem um outro também que é meu vizinho e ele conta histórias loucas que ele não viveu, ele tem visões, que uma hora ele é um presidente, uma hora ele é um político, uma hora ele é médico, então eles acham que vivem essas situações, eles imaginam, viajam. Eles têm essas visões e, às vezes, ele fala que vê bichos, que está sendo perseguindo, que vai pegar, então também é isso. Acho que é só. ACS 2

No caso de "fala desorganizada ou estranha" dizem:

[...] Porque ele não fala coisa com coisa. Outro dia ele falou que estava tendo pensamentos virtuais e que subiu no coqueiro e viu uma moça, uma lagoa, ele é assim bem confuso, não dá para conversar com ele. Mas assim, ele é calmo, ele gosta de conversar, mas assim, não tem lógica no que ele fala. ACS 9 
Os "estados emocionais extremos e lábeis", também são exemplificados:

[...] Passa 5 minutos ela volta de novo, aí conversa normal, daqui a pouquinho ela volta de novo, aí já começa querer a quebrar tudo, sai para rua e fala para o esposo dela que quer ser mendigo, que ela não quer ficar dentro de casa porque aquela casa lá não é dela, que ela não tem casa, ela fica muito violenta e ela é evangélica [...] ACS 4

O Transtorno bipolar é identificado pelo ACS pela oscilação do humor e pelo tipo de medicação em uso pelo usuário, como pode se verificar no relato a seguir:

[...] Tem de uma menina que tem problema de lítio ${ }^{13}$, que ela tem aqueles transtornos bipolares. Às vezes que eu passo na casa dela, tem hora que ela faz as coisas, tudo em casa, também tem hora que se joga lá, não faz nada, não penteia o cabelo, não toma banho. ACS 7

As características relacionadas à Depressão também são amplamente descritas pelos ACS, incluindo os aspectos diagnósticos descritos na CID 10 (OMS, 1998, p. 34) foram exemplificados pelos ACS como se vê a seguir:

O "humor deprimido ou melancólico" é assim exemplificado:

[...] começou a chorar, ela estava muito deprimida mesmo. Ela tinha estado uns 15 ou 20 dias sozinha dentro de casa, sem contato com ninguém e ela foi contando o que tinha acontecido (...). Ela pensava em morrer ACS 6

\footnotetext{
${ }^{13}$ O lítio é um tipo de psicofármaco utilizado no tratamento do Transtorno Afetivo Bipolar.
} 
No caso de "perda de interesse ou prazer" dizem:

[...] Ela se entregava (...). Ela queria dormir o dia inteiro, não estava com vontade de fazer as atividades dela, nada. ACS2

Em relação ao "sono perturbado":

[...] ele tinha insônia, às vezes eu levantava durante a madrugada para ver ele, ele estava chorando, e aí ele não queria conversa, ele se trancou no mundo dele. ACS 10

Observam, ainda, sentimentos de "culpa ou perda da autoconfiança":

[...] Ela fala que podia morrer, que eles [os filhos] não precisavam mais dela. Até já tentou, tomou alguns comprimidos. Porque ela acha que agora ela só está pesando, que ela só está atrapalhando, porque agora ela só atrapalha eles [...]. ACS 2

Em relação a "agitação ou lentidão dos movimentos ou da fala", dizem:

[...] ele é muito confuso, chego lá para falar e ele fala muito rápido, ele é estranho, ele também tem depressão. ACS 9

E, enfim, exemplificam os "pensamentos ou atos suicidas":

[...] ela estava deprimida, ela começou a chorar. (...) ficava só num canto da casa. Então, aquilo era indício de que a pessoa estava deprimida, pensando em fazer alguma besteira. Acabou soltando que ficou sozinha, qualquer dia ia se matar. ACS 8 
Os Transtornos fóbicos também são citados pelos ACS em suas intervenções, sendo caracterizados como "medo irracionalmente intenso de lugares ou eventos específicos"(OMS, 1998, p. 36),

[...] as pessoas ficaram com muito medo de alguma coisa, com muito medo de sair. Eu tenho uma usuária que não sai de casa sozinha, que não gosta de estar em lugares que tem muita gente. Ela se sente mal dentro de ônibus, em feira. ACS 5

Os usuários que sentem dor em todas as partes do corpo são presença assídua nas UBS e os ACS identificam tais situações de sofrimento mental. Na CID 10 estão definidas como Queixas somáticas inexplicadas que se caracterizam por "diversos e variados sintomas físicos sem uma explicação física" (OMS, 1998, p. 48).

[...] Ela tem mania de coceira, você vai lá e tudo coça, dor de garganta, mas é tudo psicológico porque ela passa no médico regularmente, tem convênio, o médico diz que ela não tem nada, é só dentro da mente dela que fica aquilo lá.

\section{$\operatorname{ACS} 8$}

[...] ela falava: "Eu estou com dor! Estou com dor no pé, estou com dor na perna, estou com dor no braço, eu tenho que tomar remédio". E você acabava percebendo que não era uma dor que ela estava sentindo no físico, era uma coisa a mais, mas ela não falava, ela não aceitava [...]. ACS11

Os ACS referem-se aos problemas relacionados com 0 desenvolvimento infantil como característica de sofrimento mental. 
Denomina-se Retardo mental, segundo a CID 10 o "atraso no desenvolvimento usual (caminhar, falar, treinamento dos esfíncteres)" (OMS, 1998, p.60).

[...] ela estava com problema de desenvolvimento, uma criança de 2 anos que não andava, não falava, não comia, só tomava leite. ACS 11

O Transtorno obsessivo-compulsivo caracteriza-se "essencialmente por idéias obsessivas ou por comportamentos compulsivos recorrentes" (CID-10, 1993). Os ACS citam esta característica e relatam sua inquietação ao perceberem os rituais realizados pela usuária.

[...] ela conta os carros que passam na rua, ela conta os degraus da escada, ela desce, ela sobe, ela conta de volta, se ela está cortando, preparando um alimento, se está cortando alguma coisa, ela conta cada cubinho, qualquer coisa que ela esteja cortando ela conta cada um, são manias que eu acho que devem incomodar a pessoa, dá uma aflição. ACS 6

Sabe-se dos limites dos aspectos diagnósticos e impossibilidade de adequar os sujeitos às classificações nosológicas (Cunha, 2005), mas se deve considerar aqui que foram efetuados recortes nas entrevistas com objetivo de facilitar a compreensão do leitor. Os ACS não destacam características isoladas das pessoas com sofrimento mental às quais se referem, ao contrário, abordam, nas entrevistas, aspectos como a história das mesmas, as relações que estabelecem e aspectos da convivência familiar delas. 
A partir da análise das entrevistas, verifica-se que os ACS têm condições e estão aptos para identificar situações de sofrimento mental, em especial os Transtornos psicóticos e Depressão, já que a quantidade de detalhes relacionados a este sofrimento mental é significativamente superior em relação aos demais. Observa-se ainda que há raras referências em relação aos Transtornos devido ao uso de álcool e drogas e dos sofrimentos mentais relacionados à infância.

Nos bairros onde foram realizadas as entrevistas, há pontos de comercialização de substâncias ilícitas; os ACS que circulam por todas as ruas e vielas destes bairros deparam-se com estes pontos de venda em seu cotidiano e não interferem nos mesmos, isto é, não denunciam as pessoas, com isso mantêm seu trânsito livre nestes locais.

As vendas ilícitas fazem parte da realidade dos subúrbios das grandes cidades e isto, talvez, seja uma das causas para que o Transtorno devido ao consumo indevido das drogas, praticamente, não seja citado pelos ACS como sofrimento mental.

A utilização do álcool, que é socialmente aceita, também não chama a atenção dos ACS. Souza (2005) realizou um estudo a partir dos dados do SIAB e verificou que entre os anos de 1998 e 2004 o número de pessoas cadastradas no PSF aumentou 23 vezes; já a notificação de alcoolismo nas áreas de abrangência do PSF cresceu 13 vezes. Concluiu, entre outros, que há subnotificação do alcoolismo, além de observar a inespecificidade da nomenclatura adotada, visto que alcoolismo "sequer faz parte da nomenclatura de doenças adotadas no Brasil" (Souza, 2005 , p. 342).

Os Transtornos psicóticos e Depressão foram citados por todos os ACS como sofrimento mental presente em sua área. A alta prevalência da 
Depressão entre a população em geral pode ser um dos fatores para que tal agravo seja tão citado pelos ACS, ou seja, dizem mais sobre este tipo de sofrimento porque deparam-se mais com os mesmos no exercício de sua profissão. Um terço ou mais das pessoas que procuram atendimento na atenção básica apresentam morbidade psiquiátrica menor (MPM) caracterizada por sintomas ansiosos, depressivos e somatoformes (Coutinho, Almeida-Filho, Mari, 1999).

Quanto aos Transtornos psicóticos, o fato de serem citados por todos os ACS e amplamente descritos pelos mesmos pode ser justificado pelo fascínio e curiosidade que estas situações provocam naqueles que entram em contato com as mesmas (Ferraz, 2000) e pelo conhecimento adquirido na atenção em Saúde Mental neste PSF, nas discussões regulares sobre o tema em reuniões de equipe e capacitações promovidas pela ESM. Esta equipe, em sua atuação junto ao PSF, prioriza as situações de maior gravidade, dentre eles, os transtornos psicóticos ${ }^{14}$.

Em relação ao sofrimento mental que ocorre na infância e adolescência, a OMS alerta que "dá-se insuficiente atenção a essa área da Saúde Mental" (OMS, 2001, p. 64). Os raros relatos dos ACS sobre tais problemas parecem confirmar esta preocupação da OMS, a exceção é a situação de retardo mental já mencionada. Os ACS vinculam o comportamento de uma criança como conseqüência do modo como os integrantes da família se relacionam.

[...] Eu já vi um caso de uma criança de 3 anos, muito agitada, xingava a mãe, muito nervoso e eu fui percebendo que é a família mesmo, que o problema não é só a criança,

\footnotetext{
${ }^{14}$ As situações priorizadas na atenção em saúde mental foram citadas na p. 30 como situações de risco.
} 
a avó é alcoólatra e bate no filho e ele vê tudo (...) era uma criança muito agitada, muito agressiva. ACS 9

Não apenas em relação às crianças, mas como se verificou nas sentenças selecionadas para ilustrar os aspectos diagnósticos, os ACS referem com propriedade as características das pessoas, não tratam de sintomas mas de sujeitos. Colocam a doença mental entre parênteses e mostram, desde já, que também transitam pelas noções de atenção em Saúde Mental utilizada na Reforma Psiquiátrica Brasileira.

\section{Categoria 1.3 Causas do sofrimento mental}

Segundo a OMS há diversos fatores que determinam a prevalência, o início e a evolução do adoecimento mental. "Esses fatores são sociais e econômicos, fatores demográficos como sexo e idade, ameaças graves tais como conflitos e desastres, a presença de doença física grave e o ambiente familiar [...]" (OMS, 2001, p.69).

Para os ACS as causas que determinam a ocorrência de sofrimento mental são orgânicas, sobrenaturais, as condições socioeconômicas, o ambiente familiar, situações de conflito e características da vida contemporânea.

Compõem as causas orgânicas: situações que envolvem acidentes e aspectos relacionados à hereditariedade.

[...] ela bateu a cabeça quando era adolescente numa fábrica, aí ela ficou meio transtornada. ACS 3 
Estas situações provocam alterações no funcionamento do cérebro, um "distúrbio nas células nervosas". ACS 3

A hereditariedade é citada por um ACS como um determinante de sofrimento mental, mas ele, na verdade, acredita que seja outra a causa desses problemas. Segundo ele, a psicóloga do seu filho informou que a causa do sofrimento mental do seu filho era um problema "de genética, de alguém que já tinha" na família. Em contrapartida, ao relatar situações de sofrimento mental de sua área, o mesmo ACS diz tratar-se do "fim do mundo", é como uma "poluição que vem e dá um estrago em todo mundo" ACS 4, ou seja, atribui o sofrimento mental a causas sobrenaturais.

Quanto às condições socioeconômicas, a OMS alerta para a maior prevalência de adoecimento mental entre os pobres do que entre os ricos, o que é reiterado por estudos realizados no município de São Paulo em área com unidades do PSF (Maragno et al, 2006; Cruz, Simões, Faisal-Cury, 2005). A OMS assim define "pobreza":

\begin{abstract}
Na definição mais estrita, pobreza é a falta de dinheiro ou de posses materiais. Em termos mais amplos, e talvez mais apropriados para discussões relacionadas com transtornos mentais e comportamentais, pode-se entender como pobreza um estado em que se dispõe de meios insuficientes, podendo incluir-se nisto a falta de recursos sociais ou educacionais (OMS, 2001, p.39).
\end{abstract}

A evolução do sofrimento mental é condicionada pelo grau maior ou menor de acessibilidade aos serviços de saúde, educação e assistência social (OMS, 2001; Ayres et al, 2006), tais recursos são escassos na região do município de São Paulo onde este estudo foi realizado. O relato abaixo expressa o reconhecimento dos ACS de que os fatores socioeconômicos constituem uma das causas do sofrimento mental. 
[...] este é o maior problema, a pessoa começa a ficar doente porque ela começa a pensar que ficou desempregada, o filho está desempregado, a conta começou a chegar, todo mês vem as contas, falta uma coisa, falta outra. ACS 6

Outro determinante para o sofrimento mental são as situações de "conflitos, inclusive guerras e distúrbios civis" (OMS, 2001, p.73). Os ACS observam tal determinante relacionado às situações de violência ocorridas no bairro. Pessoas que presenciaram tais situações no passado, atualmente, dependem de medicação ou passaram a fazer uso de álcool, enfim, apresentam sofrimento mental.

[...] há oito anos atrás, quando aqui começou, era muito violento, era muito violento aqui. Então muitas pessoas que estão desde o começo, depois de passar por tanta violência, ver tanta coisa, acabaram entrando na medicação, dependendo da medicação [...]. ACS 11

[...] O problema mental é de tanta desgraça na família que acontece, sabe, a questão de estar todo mundo desempregado, começar a beber, eu acho que é mais essa condição social precária [...]. ACS 7

Quanto ao ambiente familiar, a história de vida, a forma de "criar as pessoas, de criar os filhos, o meio em que elas são criadas, o meio em que elas vivem" ACS 6, também influenciam no surgimento de sofrimento mental. $O$ ambiente familiar marcado por desarmonia e violência pode ser um desencadeador, some-se a isto a vivência de situações traumáticas como perdas de pessoas queridas, perda do trabalho e assaltos. 
[...] Uma criança que vive no meio onde só tem xingamento, que ela só tem gritos, espancamento, tudo isso, ela vai guardando, assimilando aquilo ali e com maior idade vai chegar uma hora que aquilo vai explodir de alguma forma. ACS 6

A condição de trabalhador e membro da comunidade dos ACS já referida em outros momentos vai ganhando complexidade na medida em que este estudo avança. O contexto socioeconômico de desvantagem social, permeado por violência, compõe o cenário onde os ACS vivem com seus familiares e amigos. As situações de sofrimento mental que descrevem são da sua comunidade e dizem respeito ao sofrimento de seus familiares, amigos e vizinhos. A condição diferenciada dos ACS em relação aos outros integrantes do PSF para identificar os casos de sofrimento mental deve-se ao fato de serem atravessados por todas estas dificuldades e, talvez, daí derive a urgência com que almejam encaminhar as intervenções. $O$ retardo de intervenções das equipes de saúde (SF e SM) gera ansiedade nos ACS.

[...] o doutor me deu fluoxetina, uma. Aí ele não viu melhora e passou duas, estou com duas, eu tento me controlar o máximo, o máximo. Essa paciente mesmo que teve depressão pós-parto, agora que me pediu ajuda eu me segurei para não passar antes da época, nem para o TRSM, nem para equipe, me segurei para não entrar na sala e falar: "É assim, assim, assim". Mas eu estou preocupada, então eu me seguro, eu me seguro mesmo. ACS 4

Segundo a OMS

(...) a ciência psicológica mostrou que certos tipos de transtornos mentais e comportamentais, como a ansiedade e a depressão, podem ocorrer em conseqüência da 
incapacidade de fazer face adaptativamente a uma ocorrência vital estressante (OMS, 2001, p.38).

Para os ACS, o sofrimento mental é decorrente de vários excessos como de problemas, preocupações e estresse que caracterizam a vida contemporânea. Há facilidades trazidas pelos avanços tecnológicos, mas em contrapartida, multiplicaram-se as preocupações que provocam adoecimento em pessoas mais frágeis ou que não podem contar com ajuda para dividir seus problemas.

[...] Antigamente lavava uma peça de roupa, você usava fazer exercício e tal, escovava, esfregava com o braço, agora põe na máquina, é tudo mais fácil. Eu acho que o problema mental, é mais isso, está tendo muita coisa para a mente da pessoa. ACS 12

[...] É como uma gota d'água, a pessoa já está transbordando qualquer nada a pessoa entra em surto. ACS1

[...] é duro você sempre estar relutando contra alguma coisa, aí tem uma hora acho que a pessoa se esgota, não agüenta, acho que deve ter alguma alteração no cérebro, alguma coisa que as pessoas ficam meio desequilibradas, começa a ficar tenebrosa, começa a ficar com medo que nada vai dar certo, que às vezes é melhor se isolar, se afastar, por medo do problema e enfrentar. É mais fácil ficar isolada, ficar num canto do que lutar. (...) depois começa a esquecer das coisas, como se fosse querer esquecer do problema, então começa a se livrar de tudo, quer dizer, é mais cômodo você se entregar num problema, deixar que ele aconteça do que você lutar. ACS 3 
Sobre este tema diz Pereira

(...) a doença mental se revela intimamente ligada às emoções, aos sentimentos e às dificuldades de cada um para superar o problema vivido (Pereira, 2003, p. 80).

Alguns dos ACS entrevistados referiram que não sabem o que causa sofrimento mental embora achem que "qualquer um está apto a ter" ACS 1, até eles mesmos.

Verifica-se também que os ACS não fazem distinção se o sofrimento mental ocorre mais entre os homens ou entre as mulheres e, conforme já citado, se atém principalmente a ocorrência ocorre entre adultos.

A partir desses determinantes citados pelos ACS, verifica-se que a forma de compreender o processo saúde-doença mental está de acordo com as diretrizes das estratégias do PSF, Reforma Psiquiátrica e Vulnerabilidade, já que os aspectos do contexto social, os recursos disponíveis na atenção às pessoas com sofrimento mental são considerados nessa determinação.

De acordo como identificam o sofrimento e as causas que atribuem aos mesmos, os ACS direcionam as condutas nesta área, o que será apresentado a seguir.

\section{TEMA 2. As condutas dos ACS na atenção em Saúde Mental no PSF}

\section{Categoria 2.1 Ações e tratamentos}

Há, segundo os ACS, diferentes atores e ações envolvidos na atenção às pessoas com sofrimento mental de sua área. Dentre os atores, além deles próprios, que, às vezes, são protagonistas e outras são 
agenciadores das ações, há outros profissionais integrantes das ESF, da ESM e outras instituições (como os CAPS, igrejas, escolas, etc.). A assistência se inicia com a participação do próprio usuário e sua família, cuja colaboração é imprescindível no tratamento.

[...] porque não adianta nada a gente querer fazer um monte de coisas e a pessoa que a gente quer ajudar não está com vontade, não quer sair, não adianta. Tem que partir da pessoa para ela poder ser ajudada. Tudo tem uma solução mas tem que partir da pessoa. É o primeiro ponto. ACS 3

A atuação do ACS na atenção em Saúde Mental tem início na identificação de situações em que há suspeita de sofrimento mental. O segundo passo compreende a aproximação das famílias em questão para se obterem mais informações sobre a história de vida e do adoecimento da pessoa com sofrimento mental.

[...] de primeira mão eu pergunto se a pessoa está em tratamento, se a pessoa tem medicação, se a pessoa está assistida. Logo em seguida, eu colho toda a história e levo sempre na reunião [...] ACS 5

A aproximação das famílias demanda tempo e, às vezes, várias VD são realizadas em um curto espaço de tempo para estabelecer vínculo com usuários e familiares, e colher informações sobre desencadeadores do sofrimento mental, tempo de ocorrência, recursos e pessoas com quem se pode contar na condução da situação, enfim, informações que auxiliem na compreensão e encaminhamento da assistência. 
[...] eu fui puxando assunto com ela. Fui perguntando como é que ela estava, fui conversando com ela e puxando, puxando. Aí eu puxei no lado 'xis': o namorado que ela tinha. Ela começou a chorar. (...) às vezes, tenho que conversar muito com a pessoa pra puxar. Tem que entrar na casa da pessoa. ACS 8

O sentido de "entrar na casa" da pessoa a que se refere a ACS 8 parece ir além do espaço físico da moradia e referir-se à aproximação da intimidade das famílias, utiliza-se para isto de um valioso recurso que é a VD para conhecer como vivem essas pessoas, desde a dinâmica familiar até as condições de saneamento básico (Cunha, 2005). Este estreitamento das relações possibilita que as pessoas se sintam à vontade para falar, sintam confiança nos profissionais de saúde, ou seja, o ACS entende que o estabelecimento de vínculo é um facilitador para a compreensão das situações de sofrimento psíquico.

[...] se eu tivesse vínculo acho que seria muito mais tranqüilo, mais tempo de conhecimento, mais tempo de orientação, amizade, sabe Deus como que é isso. Acho que eu conseguia mais coisas, acho que sim. ACS 1

Quando as VD são insuficientes para a aproximação e caracterização das situações, outras estratégias são utilizadas, como o agendamento de consultas na UBS com outros integrantes da ESF ou ESM ou a realização de VD com estes.

Nesse momento, as ESF e ESM passam a integrar a atenção em Saúde Mental ao conhecerem as situações da área nas reuniões de equipe, ocasião esta em que se desencadeia a discussão e elaboração de 
estratégias de atenção para cada família levando-se em consideração suas singularidades (Cunha, 2005).

[...] primeiro eu ando com um caderninho, eu anoto tudo, tudo o que a pessoa vai me falando, ou que não fala e eu vejo que é estranho, aí eu venho e passo para o TRSM, porque ele entra nas nossas reuniões de equipe. Na minha área é a que mais tem [pessoas com sofrimento mental]. Sempre é a mesma coisa, acabo vendo que tem alguma coisa de estranho e trago o caso para a equipe. ACS 9

[...] Da mesma forma que agimos com uma família não podemos agir com outra família. ACS 1

O tratamento das pessoas com sofrimento mental, na ótica do ACS, inclui o uso de psicofármacos; conversas durante as VD realizadas apenas com ele ou com outros integrantes das equipes do PSF; a realização de atividades em grupos; manter-se em atividades sejam laborais, de estudo ou lazer; e as ações desenvolvidas em conjunto com outros serviços da região, como os CAPS, escolas, creches etc.

O uso de psicofármacos é um importante recurso para "reduzir ou controlar os sintomas ou evitar recidivas" (OMS, 2001, p. 93) e melhorar a interação do usuário com a comunidade desde que ele seja feito de forma adequada, isto é, com indicações e dosagens apropriadas para cada situação, e reavaliado periodicamente quanto à necessidade de manutenção. Os cuidados na administração de psicofármacos devem ser tomados para que a medicação não se torne a única resposta para as situações de sofrimento mental (Saraceno, Asioli, Tognoni, 1997).

Nas unidades de saúde do PSF, onde se deu esta pesquisa, o uso racional dos psicofármacos tem sido tema abordado pela ESM junto a todos 
os integrantes da ESF nas reuniões mensais ou em treinamentos específico sobre o tema. Essa prática contribuiu para que os ACS reconheçam a eficácia terapêutica dos psicofármacos no controle dos sintomas.

[...] Ela tem que ter medicação para ter um controle. Para ela se acalmar um pouco, eu já vi ela sem medicação, é terrível. ACS 1

[...] ela tinha crises muito graves, de agredir a família, de quebrar as coisas, era bem agressiva. Agora ela está controlada, porque ela toma a medicação [...] ACS 6

A mesma medicação que possibilita o controle de um sofrimento psíquico, se administrada em excesso, provoca o adoecimento. Há pessoas que utilizam drogas terapêuticas há tanto tempo, sem nenhuma avaliação profissional, que nem se sabe se são necessárias ou não e qual o motivo que as levou a iniciarem este uso.

[...] Às vezes os próprios remédios deixam a pessoa mais mole, grogue, mais desanimadas porque ele acalma, ele relaxa tudo. Nunca as pessoas tomam remédio e param, elas vão tomando, tomando, e o remédio também fica deixando a pessoa meio mole, meio deprimida, meio desanimada. ACS3

Assim, uma das condutas dos ACS no controle do sofrimento mental se refere ao monitoramento da medicação utilizada: contagem dos medicamentos, observação da ingestão de medicamento e orientação quanto à renovação de receitas e agendamento de consultas para avaliação da necessidade de manutenção do uso e dosagem. 
[...] é mais esta questão de ficar sempre atenta, de estar perguntando, ficar de olho na pessoa, principalmente na medicação de quem usa. ACS 7

Para os ACS o que deve ser "associado à medicação é a conversa" ACS1. 'Escutar' é uma das principais atitudes terapêuticas dos trabalhadores dos serviços de saúde em relação aos usuários. Ouvir as pessoas com atenção, fazer-lhes companhia, falar sobre temas que interessem e orientá-las (quanto a atividades, cuidados pessoais, cursos), são ações que os ACS desenvolvem em seu cotidiano na atenção em Saúde Mental pois entendem isto como uma forma de tratamento (Saraceno, Asioli, Tognoni; 1997).

[...] eu falo: "Hoje eu estou disponível pra te ouvir", conversar, convidar pra passear, sorrir com ela, fazer com que ela lembre de coisas passadas boas (...). O fato de estar ali pra ouvi-lo, pra conversar, acolher o que ele tem pra passar é muito importante. ACS 5

Ouvir é, assim, uma forma de melhor compreender a situação e também de acolher as pessoas com sofrimento mental da área. Às vezes, esta atitude pode ultrapassar os limites do tempo e local de trabalho dos ACS.

As atividades em grupo, identificadas como uma das formas de tratamento para as pessoas com sofrimento psíquico, constituem outra possibilidade para que as pessoas possam ser ouvidas, dentre elas está o grupo de autocuidado.

[...] fiquei uma tarde inteira ouvindo, mas foi bom, porque agora a gente já tem um caminho para conversar com ela, 
para tentar ajudar ela a resolver, ela está com isso há mais de anos. ACS 6

[...] a gente montou um grupo de autocuidado, (...) às vezes essas pessoas querem só conversar, conversando, colocando aquele sentimento para fora, já melhorava bastante. (...) seria um espaço mesmo de convivência, de conversa para a gente melhorar essa situação. ACS 10

Na situação descrita acima, o ACS relata a importância de ouvir a pessoa, mesmo que se utilize de um tempo maior que o sugerido para uma VD. No Documento Norteador da PMSP 2005-2006 ${ }^{15}$ recomenda-se que cada ACS realize, em média, dez VD por dia para cumprir a meta de cobertura de, no mínimo $70 \%$ das famílias de sua microárea no mês.

A preocupação com o cumprimento de metas pode levar os ACS a reconsiderarem a realização de VD mais prolongadas por uma questão burocrática, sem uma reflexão sobre os objetivos e limites desta atividade.

Grupos de terapia comunitária ${ }^{16}$, passeios, grupos de artesanato, caminhada são atividades realizados pelos ACS na unidade de saúde ou na comunidade. Na terapia comunitária, realizada com regularidade em 5 UBS deste PSF, os ACS percebem mudanças positivas na vida das pessoas que a freqüentam.

[...] convidamos muita gente para a terapia comunitária porque a acho que ajuda. Acho não, percebo que ajuda.

\section{ACS 1}

\footnotetext{
${ }^{15}$ Documento que estabelece as diretrizes para a organização do serviço na atenção básica de saúde, elaborado pela Secretaria Municipal de Saúde de São Paulo (São Paulo, 2005d).

${ }^{16}$ No ano de 2004 ACS do PSF/Zerbini - Região Sudeste concluíram o curso de Terapia Comunitária realizado pela Prefeitura municipal de SP e passaram a realiza grupos em geral semanais nas UBS.
} 
Ainda os ACS coordenam ou colaboram com grupos de artesanato, cozinha natural, caminhada, passeios, autocuidado e com atividades em dias comemorativos como o Dia das crianças, de Luta contra Aids, etc. Esses grupos não são exclusivos para pessoas com sofrimento mental, qualquer morador da área pode participar.

A atividade em grupo é considerada um recurso terapêutico na visão dos ACS, pois exige a atenção da pessoa com sofrimento mental, desviando-a de preocupações com seus problemas e delírios.

[...] O esquizofrênico, você medica, você normaliza a situação dele, e aí você dá situações para ele sempre estar sempre com a mente ocupada, para ele não ficar vazio; porque eu acredito, não sei se estou certa, que a pessoa que já tem este problema - fica vendo coisas, ouvindo coisas, sendo perseguido, achando que tem gente para matar, quanto mais tempo ela ficar só, mais enrolado ela fica, mais produção ela vai ter na cabeça dela, mais situação de risco para ela, ela vai produzir na cabeça. ACS1

Os ACS apresentam, assim, uma noção do senso comum sobre a realização de atividades, como diz o ditado popular "cabeça vazia é oficina do diabo". Sobre este tema, Nascimento (1990), abordando a atividade do terapeuta ocupacional, diz que, embora haja um mito de que toda atividade pode ser terapêutica, há atividades que são apenas ocupação, exercício, recreação, ou seja, as atividades não são terapêuticas em si mesmas e que, para sê-lo, a situação concreta de vida das pessoas deve ser considerada. As atividades podem ser uma etapa do projeto terapêutico mas não um fim, "não necessitamos que [pessoas com sofrimento mental] façam cinzeiros, necessitamos que exerçam a cidadania" (Saraceno, 2001, p.16). 
Quanto as atividades, os ACS acrescentam ainda que compreendem que tratamento é dedicar-se ao trabalho e as atividades que dão prazer.

[...] Tratamento é procurar fazer o que sente mais, com vontade, mais prazer, do que tomar certos tipos de medicação. Dependendo da situação de cada um, depende do grau. Vamos supor, se a pessoa está agitada com alguma coisa, se ela procurar distrair um pouco, ficar mais tranqüila, a pessoa consegue fazer, melhor do que tomar um calmante para dormir, acorda o problema está maior ainda. ACS 12

[...] ela começou a trabalhar, a fazer uma coisa que ela gosta que é cuidar de criança, aí eu percebi que ela estava melhorando. ACS 11

Se, como foi dito anteriormente, o padrão 'normal' de comportamento para os ACS está relacionado a manter-se em atividade e socializar-se, a realização dos grupos pode ser compreendida como um meio de prevenção e de tratamento do sofrimento mental, considerando que no interior dos grupos ocorre a socialização.

Como articulador, os ACS apresentam as situações de sofrimento mental para discussão em equipe e participa da elaboração das estratégias de ação. Uma destas ações pode ser a realização de VD com outros integrantes da ESF e ESM.

Nessas VD, a direção da conversa, diz o ACS, fica sob a responsabilidade do técnico, "o profissional que comanda" ACS 8. Nessa ocasião a participação do ACS é realizada com cautela. 
[...] Na hora que o TRSM está lá falando com a família, eu não interfiro, eu só me coloco, se tiver uma situação pra eu me colocar (...) deixo o profissional agir, eu não sou. ACS 2

Uma outra conduta dos ACS frente ao sofrimento mental identificado foi o aconselhamento leigo, como de um amigo ou conhecido. Nessas situações acha que as técnicas deveriam ser deixadas de lado e "ir no popular" ACS 2, por isso em algumas oportunidades dão conselhos.

[...] Eu sempre dou conselho, eu falo para procurar pensar em coisas boas, pensar mais em Deus, em se tratar, agora tem o apoio da terapia [comunitária], tento animar a pessoa, eu falo: "Não fica assim, procure ver as coisas por outro lado, tem outras pessoas que estão com problemas maiores". (...) Aí eu falei para ela: "Procura não ficar assim tão ansiosa nesse relacionamento porque depois ele vai embora, procura ter calma, fica tranqüila". ACS 3

A prática do aconselhamento, nos moldes como é realizado pelo ACS, conflita com a recomendação de Saraceno, Asioli, Tognoni na abordagem de pessoas com depressão

Não aconselhar e não estimular o paciente a ser ativo para não aumentar o sentimento de culpa (Saraceno, Asioli, Tognoni, 1997, p. 61).

Não é esperado que os ACS, no exercício de suas atribuições, se atenham a este tipo de preocupação, ou seja, o quanto é apropriado ou não aconselhar. Mas neste PSF em que há uma ESM participando do cotidiano das equipes, o tema é abordado em reuniões e treinamentos. Outra reflexão, mais uma vez retomada, é que os ACS são moradores da área, ou seja, dá 
conselhos para aqueles que são seus vizinhos e amigos. Agir por intuição quando não se tem formação suficiente também foi o resultado observado por Nascimento, Braga (2004) no estudo sobre a prática de médicos e enfermeiros na atenção em saúde mental do PSF de Caucaia, Ceará.

O papel dos ACS como 'elo' entre o serviço de saúde e comunidade citado em documentos sobre o PSF é reconhecido pelos próprios ACS ao verificarem que seus encaminhamentos resultaram em atenção à pessoa com sofrimento mental.

[...] eu me sinto um elo de um tratamento para essa pessoa e eu fico muito feliz quando eu consigo dar andamento num caso [...]. ACS 5

Com todas as ações já descritas e, partindo do princípio de que a garantia de acessibilidade já é o início do processo terapêutico, o 'elo' que o ACS estabelece é uma ação de saúde para as famílias com situações de sofrimento mental, identificando o caso e levando-o para a equipe. No entanto, o ACS parece não valorizar essa modalidade de ação, pois, embora relate as ações que realiza e identifica como terapêuticas (monitorar medicação, conversar), às vezes, considera como parte de suas atividades, apenas acompanhar os técnicos das ESM. Neste aspecto, sua fala reforça a idéia de que as intervenções em Saúde Mental só podem ser realizadas por técnicos da Saúde Mental. Em alguns momentos o ACS manifesta inclusive que sente medo de fazer alguma coisa errada.

[...] Às vezes ficamos um pouco perdidos. Temos medo de fazer uma coisa e estar errado, ficamos meio receosos em relação a estes pacientes. Porque se fizermos uma coisa que está errada, depois pra pessoa aderir ao tratamento, aderir alguma coisa que é certo, custa muito tempo. Tem 
que ter o máximo de cuidado, como dizem 'pisar em ovos'. $\operatorname{ACS} 8$

Como articulador, os ACS realizam agenciamentos com outras instituições como os CAPS, Alcoólicos Anônimos, Conselho Tutelar e hospitais psiquiátricos.

No distrito de Vila Prudente/Sapopemba há dois CAPS para atenção aos adultos com sofrimento mental, estes "constituem a principal estratégia do processo de reforma psiquiátrica" pois são serviços substitutivos dos hospitais psiquiátricos (Brasil, 2004c, p.9). Os ACS atribuem importância às atividades realizadas no CAPS, da mesma forma que nas UBS como os grupos de atividades.

[...] Tem outro que fez tratamento no CAPS (...) fazia trabalho lá, ficava durante o dia, fazia alguma coisa, voltava. Hoje, sinceramente, você nem vê, nem conhece, não dá para conformar, ele com problema, ele é normal, ele é um anjo. ACS 1

E tecem uma crítica ao CAPS devido à forma de encaminhamento das pessoas com sofrimento mental para atendimento no PSF, por referirem apenas a medicação em uso, omitindo qualquer informação sobre as pessoas, sua vida, história, constituição familiar entre outros que podem auxiliar no planejamento das intervenções dando continuidade ao projeto terapêutico.

[...] tem os casos de lá do CAPS que voltaram tudo para a unidade e a unidade tem que começar do zero, porque a gente recebe muito pouco do CAPS, tem casos que vieram 
de lá que vem com a receita de anos e anos a fio. (...) $O$ encaminhamento vem assim: o nome da pessoa, a idade $e$ o endereço, para psiquiatria, nada de histórico, quando você pede o histórico, o prontuário de lá do CAPS não tem nada, só tem que passou dia tal, troca de receita, diazepan, um comprimido de manhã e um comprimido à noite, nada, nada, nada. E isso há quanto tempo? Cinco anos [...]. ACS 10

O relato acima evidencia que o ACS compreendeu "que é necessário colocar a doença entre parênteses”, como afirmou Basaglia (1985), e que a atenção deve voltar-se para a pessoa que sofre, não para a doença, ou seja, a atenção vai além de tomar remédios, de acordo com as estratégias norteadoras deste estudo.

Os ACS são assim agentes de Saúde Mental, protagonistas da Reforma Psiquiátrica Brasileira, alertando para o fato de que não é apenas a criação de serviços que vai romper a lógica manicomial.

Em relação aos hospitais psiquiátricos, "o pior hospital que tem" ACS2, os ACS relataram que, às vezes, sugerem às famílias levar a pessoa com sofrimento mental para essas instituições devido ao receio de não saberem como agir em uma situação de crise.

\footnotetext{
[...] Por eu não ter conhecimento, não ter amizade, sinceramente, eu fiquei com certo receio de chegar e ele não me aceitar bem. Então eu preferi orientar a família a levar para o hospital porque não tinha como ficar. Ele estava agressivo. ACS 1
} 
Situações como esta, às vezes, nem chegam a ser discutidas com as ESF e ESM, mantendo a pessoa com sofrimento mental no ciclo criseinternação-crise.

[...] ficou toda a vida dela internada. Ela vinha para casa, ficava um mês, aí dava uma crise e eles internavam. ACS11

A conduta dos ACS em relação às pessoas que fazem uso indevido de álcool e a suas famílias é de orientação e encaminhamento para instituições como o Alcoólicos Anônimos.

[...] tem aqui o AA. Eu sempre falo para a pessoa estar participando e a família também. Porque geralmente a família acha que ele é sem vergonha, ele bebe, mas não é, é uma doença, a família não sabe como lidar com isso, a gente fala para a pessoa que é para a família acompanhar também as reuniões do AA. ACS 9

Por fim, o apoio espiritual, é citado como necessário ao tratamento das pessoas com sofrimento mental. Dentre os doze ACS entrevistados apenas dois referiram-se aos aspectos religiosos relacionados aos sofrimentos mentais e orientam seus usuários a buscarem este apoio que traz resultados positivos para as pessoas.

[...] Hoje ele vai pra igreja. Aceitou se tratar. Ele achava que estava ficando louco e viu que não estava, que estava com depressão, estava desempregado. Hoje eu vejo que houve um resultado muito bom. Foi a base de remédio também mas acho que o espiritual ajudou muito ele. ACS 8 


\section{Categoria 2.2 Facilitadores e dificuldades na atenção em Saúde Mental}

Os ACS ao identificarem as situações de sofrimento mental de sua área, se apropriam destas situações e apresentam com detalhes as características e histórias das pessoas em sofrimento mental e suas famílias, demonstrando que as reconhecem como problemas de saúde. Essa identificação está vinculada às causas e/ou condições que determinam a ocorrência do sofrimento mental, na ótica dos ACS. Assim, considera-se que a concepção de situações de sofrimento mental desses ACS constituiu um facilitador da atenção em Saúde Mental, pois incluiram no rol de suas atividades a atenção às pessoas nessas condições.

Os ACS reconhecem que sua qualificação advinda das capacitações promovidas pela ESM e a atuação do TRSM em sua área é um facilitador do seu trabalho.

[...] No momento, o que está facilitando muito é o TRSM quando a gente tem dúvida. Antes ele veio explicou para a gente alguns casos, praticamente uma capacitação, num primeiro momento que ele chegou aqui falando com a gente. (...) Antes dele, às vezes, a gente deixava até passar desapercebido algumas coisas, porque a gente não tinha uma referência, mas às vezes você colocava algumas coisas mais para o enfermeiro e o enfermeiro também, por não ter um apoio como essa referência que a gente tem agora, então não tinha muito o que fazer, só em casos muito críticos mesmo a gente mandava para outros lugares. Então agora o que está facilitando muito é o TRSM. ACS 7

Os ACS apontam, também, como elementos facilitadores algumas necessidades, que se satisfeitas, podem aprimorar sua atuação: a necessidade de contar com a assistência da ESM para problematizar as angústias que enfrentam na realização de suas atividades; a necessidade de 
aumentar a freqüência das capacitações desenvolvidas por essa equipe e, aumentar o número de profissionais que a integram.

[...] A gente pede para ter um grupo para a gente, um tempo mais para a gente, porque a gente só trabalha, trabalha, aí a gente vai ficando cansada, se tivesse um grupo que a gente se soltasse mais, uma terapia para 0 agente comunitário (...) ACS 11

[...] alguma conversa, uma roda de conversa com um TRSM, às vezes até uma angústia nossa mesmo, tanto da família como da população da nossa micro, ter um momento para fazer uma roda comunitária, desabafar seus problemas, falar, eu acho que isso pelo menos a cada dois meses, eu acho que seria interessante para a gente estar fazendo entre os funcionários, acho que ajuda. ACS 7

[...] mais capacitação. Como abordar um usuário que esteja com estes problemas. Porque, às vezes, nós não temos aquela informação. Temos informação porque convivemos com estas pessoas, porque visitamos elas mas não temos aquela capacitação de como reagir no momento. ACS 8

[...] (precisamos de) mais pessoas da Saúde Mental, mais psiquiatras, mais psicólogos [...] ACS 3

$\mathrm{Na}$ região em que foi realizado este estudo, o PSF iniciou suas atividades no ano de 1998 em cinco UBS, com quinze ESF e quatro TRSM. A expansão do número de ESF para 42, distribuídas em 9 UBS, não foi concomitante a ampliação da ESM e algumas UBS ficaram sem referência da ESM até 2005, dificultando a atenção em Saúde Mental, situação esta que justifica a necessidade mencionada pelos ACS de ampliar as ESM. 
Ainda, em relação a este aspecto da ampliação da ESM vale considerar que, embora os ACS identifiquem a situação social como um dos principais determinantes do sofrimento mental, os encaminhamentos por eles realizados na resolução dos problemas, se limitam ao o campo da saúde. Reconhece-se aqui uma contradição entre a causa/determinação do agravo e a transformação possível, ao não se propor, por exemplo, o agenciamento intersetorial ou a mobilização social para que as condições de vida sejam modificadas, ou seja, há a psicologização dos problemas sociais e cotidianos e não a busca do empoderamento do sujeito por meio de ações intersetoriais (Silveira, 2003).

Quanto às dificuldades na atenção em saúde mental, os ACS relatam experimentarem diversos sentimentos, como o medo de serem agredidos fisicamente pelas pessoas com sofrimento mental.

[...] eu chegava lá e pensava já pensou se ele pega no meu pescoço, sei lá, tinha medo mesmo, porque a fisionomia dele era assustadora [...] ACS 9

Foram relatados outros sentimentos, como angústia ao entrarem em contato com situações de pobreza, maus tratos, negligência e as conseqüências da violência em sua área. São situações que os ACS já conheciam ou passaram a ter maior contato a partir de seu ingresso neste trabalho, entre elas, as situações de pobreza, negligência e violência.

[...] Para mim é um pouco triste, fico um pouco abalada. Antes eu ficava muito abalada. (...) eu já tinha entrado num pedaço da favela, mas eu não tinha visto de tão dentro assim da favela, as coisas que aconteciam, umas pessoas sem nada, o esgoto passando no meio da casa, eu ficava um pouco abalada. ACS 3 
[...] eu sofria muito porque eu não aceitava ver uma pessoa idosa, velhinha, na cama, estava cega e os filhos não queriam saber de nada, ela ficava lá toda suja, com resto de comida em cima da cama e aquilo para mim era terrível, eu não conseguia aceitar essas coisas, eu chorava muito, eu não conseguia dormir porque eu não conseguia resolver. $\operatorname{ACS} 4$

[...] os dramas das mães, os filhos assassinados, delas quererem que eles voltem. (...) Eu tenho filhos também, muitas vezes fico imaginando, me coloco como se fosse eu, tenho muito dó. ACS 2

Diante destas situações do sofrimento humano de sua comunidade, o ACS tem pressa de resolver os problemas e teme também adoecer e perde o sono pensando nestas situações. Dessa maneira, a demora nos encaminhamentos traduz-se em uma dificuldade para a atenção em Saúde Mental:

[...] Eu tento, ao máximo, não me deixar levar porque eu sei que se eu ficar doente também, não vai ter quem as ajude a se reerguer. (...) Eu tento me segurar ao máximo, mas tem noite, assim, que eu não durmo. (...) Eu sinto vontade de, se eu pudesse, ser o super homem, como eles dizem nos quadrinhos, pra resolver tudo. Às vezes a gente vê aquela situação e não pode fazer nada, tem que esperar 0 tempo falar, o tempo dizer. Não podemos fazer naquele momento e a vontade do agente comunitário é resolver naquele momento, é levar a solução naquele momento. ACS 8 
O impossível de ser realizado, como o desejo de ser um "super herói" para resolver todos esses problemas, é permeado por sentimentos, como o sofrimento e impotência ao lidar com a morosidade e inexistência de serviços de saúde ou outras áreas para encaminharem as situações.

Compreende-se, assim, a partir dos relatos dos ACS o motivo de seu pedido por conversas sobre as angústias presentes em seu trabalho, mas, como afirma Martines (2005)

(...) até o momento, não há um espaço institucional, seja ele qual for, para dar continência a essa angústia e trabalhar o entendimento da subjetividade desse profissional [ACS], quando falamos de emoções, sobrecarga ou sofrimento (Martines, 2005, p.33).

A proximidade dos ACS com a comunidade, que é um facilitador para o acesso às famílias, também pode ser um empecilho se a família simplesmente não quiser que a situação de adoecimento, não só de Saúde Mental, seja conhecida pelos ACS, que pode ser seu vizinho, amigo de infância, amigo da família ou parente.

Os ACS que relataram sua vivência, pessoal e familiar, de sofrimento mental não referem que isto seja uma dificuldade na atenção às pessoas em sofrimento mental, uma das hipóteses formuladas.

Quanto a hipótese de que o excesso de trabalho poderia levar os ACS a não relatarem as situações de sofrimento mental já que, em geral, estas situações demandam um número maior de VD por mês, verificou-se que em nenhum momento os ACS referiram ter trabalho demais, 
incomodam-se apenas com a quantidade de trabalhos burocráticos cotidianos, como preenchimento de fichas e planilhas.

Um outro aspecto que pode ser considerado como dificuldade na atenção em Saúde Mental diz respeito à compreensão dos ACS de que há situações em que somente os técnicos em saúde mental podem promover ações de saúde mental. Fazem menção às situações em que temem não estar agindo corretamente, pois reconhecem um modo leigo de agir. A desconstrução de noções como esta, da especialidade na atenção e a solicitação dos ACS indicam, como foi suposto, que as capacitações tem sido insuficientes para abranger os diferentes aspectos relacionados à atenção dos ACS na assistência às pessoas com sofrimento mental.

Os ACS relataram dificuldades importantes na atenção às pessoas com sofrimento mental que certamente não abarcam todos os problemas vivenciados nesta atenção, mas dão indícios de rumos e recomendações a seguir. 


\section{CONSIDERAÇÕES FINAIS}

O estudo respondeu as questões iniciais e trouxe subsídios para novas reflexões sobre o tema bem como para ações que facilitem a efetividade na atenção em saúde mental no PSF.

A identificação de pessoas com sofrimento mental e sem tratamento no território de abrangência do PSF foi a inquietação disparadora desta investigação.

Os ACS reconhecem as situações de sofrimento mental, compreendem, por exemplo, que uma pessoa que diz 'ouvir vozes' ou 'pensa em dar fim a própria vida' necessita de atenção em saúde mental, independente de denominar isto de 'delírio' ou 'ideação suicida'. Estabelecem uma relação de proximidade com estas pessoas e suas famílias e reconhecem diferentes tipos de tratamentos para as mesmas, entre os quais destacam o uso de medicação e a participação destas pessoas em atividades. Entendem, ainda, que há vários fatores desencadeantes para o sofrimento mental, destacando os socioeconômicos. Relatam receios na atenção aos portadores de sofrimento mental, insuficiência de apoio técnico e solicitam mais capacitação.

Levando-se em consideração a dimensão programática da Vulnerabilidade, a participação expressiva dos ACS na identificação e na assistência de pessoas em sofrimento mental, dada a sua inserção na comunidade e a sua atuação no território, pode-se afirmar que contribuem para minimizar a vulnerabilidade das pessoas ao adoecimento mental à medida que contribuem para que o diagnóstico ocorra precocemente. Este diagnóstico se dá, entre outros, pelo acolhimento das pessoas quando 
procurado e pelo encaminhamento das situações no sentido de articular o acesso ao serviço.

O trabalho dos ACS contribui na atenção ao sofrimento mental no território e pode proporcionar uma porta aberta para que as 'situações escondidas' cheguem até os serviços de saúde. Porta esta que se fecha ao se considerar as dificuldades na atenção em saúde mental vivenciadas pelos ACS.

Algumas ações, assim, se fazem necessárias para facilitar este trabalho como:

- monitorar os dados de atenção em saúde mental no território adscrito do PSF, possibilitando o conhecimento da magnitude das situações de sofrimento mental e dos resultados do trabalho desenvolvido;

- promover discussões temáticas junto aos ACS sobre o contexto econômico, político e social e suas implicações na saúde;

- estimular a participação dos ACS e da comunidade na luta por direitos sociais;

- discutir junto às coordenações do PSF e gestores da SMS a necessidade de suporte institucional para as ESF e sistematização de capacitações em saúde mental.

Concluindo, verificou-se que a despeito de algumas dificuldades enfrentas pelos ACS na atenção aos portadores de sofrimento mental, esta está ancorada nos princípios da Reforma Psiquiátrica Brasileira de inclusão e atenção na comunidade. Os ACS são protagonistas desta atenção e a inclusão de equipes de referência em Saúde Mental, proposta pelo MS, auxiliará numa atenção que promova a cidadania plena dos portadores de sofrimento mental.

Algumas questões respondidas e outras que se colocam: Quais serão os significados e as ações em Saúde Mental dos ACS de PSF onde não há 
ESM? Serão semelhantes aos encontrados neste estudo? Se realizássemos uma busca ativa na população atendida neste PSF, quantas e quais as situações de transtornos mentais mais seriam encontradas?

Os resultados obtidos foram, assim, apenas o ponto de partida para novas investigações e ações que se fazem necessárias na prática. 


\section{REFERÊNCIAS BIBLIOGRÁFICAS}

Alves VS. Um modelo de educação em saúde para o Programa Saúde da Família: pela integralidade da atenção e reorientação do modelo assistencial. Interface Comunic Saúde Educ. set. 2004-fev. 2005;9(16):3952.

Amarante $\mathrm{P}$, coordenador. Loucos pela vida: a trajetória da reforma psiquiátrica no Brasil. Rio de Janeiro: Fiocruz; 1995.

Amarante P. O Homem e a serpente: outras histórias para a loucura e a psiquiatria. Rio de Janeiro: Fiocruz; 1996.

Amarante P. Loucura, cultura e subjetividade. Conceitos e estratégias, percursos e atores da reforma psiquiátrica brasileira. In: Fleury $S$, organizadora. Saúde e democracia: a luta do CEBES. São Paulo: Lemos; 1997. p. $163-85$.

Amarante P, coordenador. Saúde mental: políticas e instituições. Rio de Janeiro: Fiotec/Fiocruz; 2003.

Antunes EH, Pereira LMF. Saúde mental e Programa Saúde da Família: proposta de cadastramento por agentes comunitários de saúde. In: Anais do $7^{0}$ Congresso Brasileiro de Saúde Coletiva; 2003 jul. 29- ago. 2; Brasília. Brasília: ABRASCO; 2003. p. 24.

Ayres JRCM, França Júnior I, Calazans GJ, Saletti Filho HC. Vulnerabilidade e prevenção em tempos de AIDS. In: Barbosa RM, Parker R, organizadores. Sexualidade pelo avesso: direitos, identidades e poder. Rio de Janeiro: IMS/UERJ; 1999.

Ayres JRCM, França Júnior I, Calazans GJ, Saletti Filho HC. O conceito de vulnerabilidade e as práticas de saúde: novas perspectivas e desafios. In: Czeresnia D, Freitas C, organizadores. Promoção da saúde: conceitos, reflexões, tendências. Rio de Janeiro: Fiocruz; 2003. p.117-39.

Ayres JRCMA, Calazans GJ, Saletti Filho HC, França Júnior I. Risco, vulnerabilidade e práticas de prevenção e promoção da saúde. In: Campos GWS, Minayo MCS, Akerman M, Drumond Júnior M, Carvalho YM, organizadores. Tratado de saúde coletiva. São Paulo: Hucitec; 2006.

Barros HMT, Ferigolo M, Hortiz LN. Manual para prescrição de psicofármacos. Porto Alegre: Dacasa; 1999.

Basaglia $F$ (organizador). A instituição negada: relato de um hospital psiquiátrico. Rio de Janeiro: Graal, 1985. 
Birman J. Interpretação e representação na saúde coletiva. Physis: Rev Saúde Coletiva. 1991;1(2): 7-22.

Bodstein Regina. Atenção básica na agenda da saúde. Ciênc Saúde Coletiva [periódico na Internet]. 2002 [citado 2007 abr 30]; 7(3):[cerca de 12 p.].

Disponível em: http://www.scielo.br/scielo.php?script=sci arttext\&pid=S1413$\underline{81232002000300002 \& \operatorname{lng}=\text { pt\&nrm=iso }}$

Boletim do Conselho de Saúde. São Paulo: Prefeitura Municipal, Conselho Municipal de Saúde; 2004;1(2).

Brasil. Ministério da Saúde. Saúde da Família: uma estratégia para a reorientação do modelo assistencial. Brasília; 1997.

Brasil. Ministério da Saúde. Secretaria de Assistência à Saúde, Coordenação de Saúde da Comunidade. SIAB: Sistema de Informação de Atenção Básica: manual. Brasília; 1998a.

Brasil. Ministério da Saúde. Secretaria de Assistência à Saúde. Coordenação de Saúde da Comunidade. Assessoria de Comunicação Social. Programa de formação dos agentes comunitários de saúde. [videocassete]. Brasília; 1998b.

Brasil. Ministério da Saúde. Secretaria de Políticas de Saúde. Departamento de Atenção Básica. Informes Técnicos Institucionais: Programa de Saúde da Família. Rev Saúde Pública. 2000; 34(3):316-9.

Brasil. Ministério da Saúde. Departamento de Políticas de Saúde, Departamento de Atenção Básica, Secretaria de Assistência à Saúde, Área Técnica de Saúde Mental. Proposta preliminar: "Plano de inclusão de ações de saúde mental na atenção básica”. Brasília; 2001a.

Brasil. Lei n. 10.216, 06 de abril de 2001, dispõe sobre a proteção e os direitos das pessoas portadoras de transtornos mentais e redireciona 0 modelo assistencial em saúde mental. Diário Oficial da União, Brasília, 9 abr. 2001b. Seção 1, p. 2

Brasil. Ministério da Saúde. Legislação em Saúde Mental 1990-2002. 3ํㅡ ed. Brasília; 2002a. (Série E. Legislação de Saúde).

Brasil. Ministério da Saúde. Relatório final da $3^{\underline{a}}$ Conferência Nacional de Saúde Mental: 2001. Brasília; 2002b.

Brasil. Lei n. 10.507, de 10 de julho de 2002, cria a profissão de Agente Comunitário de Saúde e dá outras providências. Diário Oficial da União, Brasília, 11 jul. 2002c. Seção 1, p. 1. 
Brasil. Ministério da Saúde. Secretaria de Atenção à Saúde. Saúde mental e atenção básica: o vínculo e o diálogo necessários. Brasília: Coordenação de Saúde Mental, Coordenação de Gestão da Atenção Básica; 2003.

Brasil. Ministério da Saúde. Conselho Nacional de Saúde. Relatório final da $12^{\text {a }}$ Conferência Nacional de Saúde. Brasília; 2004a.

Brasil. Ministério da Saúde. Informe da Atenção Básica 21: dez anos de saúde da família no Brasil. Brasília; 2004b.

Brasil. Ministério da Saúde. Secretaria de Atenção à Saúde. Departamento de Ações Programáticas Estratégicas. Saúde mental o SUS: os centros de atenção psicossocial. Brasília; 2004c.

Brasil. Ministério da Saúde. Departamento da Atenção Básica. Guia prático do Programa Saúde da Família. [texto na Internet]. Brasília; 2004d. [citado 2007 abr. 29]. Disponível em: http://dtr2004.saude.gov.br/dab/caadab/documentos/guia psf.pdf

Brasil. Ministério da Saúde. Portal da Saúde: apresenta a composição e organização das ESF. [homepage na internet]. Brasília; 2006. [atualizado em 27 abr. 2007, citado 2007 abr. 27]. Disponível em: www.saude.gov.br

Brasil. Ministério da Saúde. Secretaria de Atenção à Saúde/DAPE. Saúde Mental no SUS: acesso ao tratamento e mudança do modelo de atenção. Relatório de Gestão 2003-2006. Brasília; 2007.

Calipo SM. Saúde, Estado e Ética - NOB/96 e lei das organizações sociais: a privatização da instituição pública na saúde? [dissertação] São Paulo (SP): Escola de Enfermagem, Universidade de São Paulo; 2002.

Campinas. Secretaria Municipal de Saúde. Programa Paidéia de Saúde da Família. Campinas; 2001. [texto na Internet]. [citado 2007 abr. 28] Disponível em: www.campinas.sp.gov.br/saude/diretrizes.htm

Capistrano Filho D. O Programa de Saúde da Família em São Paulo. Est Avançados. 1999;13(35):89-99.

Capistrano Filho D. O Programa Saúde da Família. In: Anais do $6^{a}$ Congresso Brasileiro de Saúde Coletiva; 2000 ago. 28-set. 01; Salvador. Salvador: ABRASCO; 2000. p. 89-100.

Coutinho ESF, Almeida-Filho N, Mari JJ. Fatores de risco para morbidade psiquiátrica menor: resultados de um estudo transversal em três áreas urbanas no Brasil. Rev Psiquiatr Clin [periódico na Internet]. 1999; [citado 
2007 abr. 30]; 26(5):[cerca de 17 p.]. Disponível em: www.hcnet.usp.br/ipg/revista/r265/artigo(246.htm

Cruz EBS, Simões GL, Faisal-Cury A. Rastreamento da depressão pós-parto em mulheres atendidas pelo Programa Saúde da Família. Rev Bras Ginecol Obstet. 2005;27(4):181-8.

Cunha GT. A construção da clínica ampliada na atenção básica. São Paulo: Hucitec; 2005.

Cury CFMR. Família do doente mental: os significados atribuídos pela equipe do Programa Saúde da Família [dissertação]. Ribeirão Preto (SP): Escola de Enfermagem, Universidade de São Paulo; 2005.

Dell'Acqua G, Mezzina R. Resposta à crise. In: Delgado J, organizador. A loucura na sala de jantar. Santos: [s.n.]; 1991. p.53-79.

Elias P, Nakamura E, Cohn A. A implantação do Programa de Saúde da Família na metrópole paulista 2001-2003. Rev Bras Saúde Família. 2003;5(7):62-71.

Fernandes ME, Dowbor TP, Kretzer MR, Gouveia I, Sucupira AC, Menezes L, et al. AIDS: prevenção porta a porta: construindo histórias de prevenção ao HIV/AIDS no Programa Saúde da Família da cidade de São Paulo. São Paulo: Associação Saúde da Família: Hucitec; 2004.

Ferraz FC. O louco de rua visto através da literatura. Psicol USP [periódico na Internet]. 2000; [citado 2007 abr. 30]; 11(2):[cerca de 30 p.]. Disponível em: $\quad<\mathrm{http}: / / w w w . s c i e l o . b r / s c i e l o . p h p ? s c r i p t=s c i \_a r t t e x t \& p i d=S 0103-$ $65642000000200009 \&$ lng $=$ pt\&nrm=iso $>$.

Fortes PAC, Spinetti SR. O agente comunitário de saúde e a privacidade das informações dos usuários. Cad Saúde Pública. 2004;20(5):1328-33.

Franco T, Merhy E. PSF: contradições e novos desafios [texto na Internet]. Brasília: [s.n.]; 1999 [citado 2007 abr. 27]. Disponível em: http://www.datasus.gov.br/cns/temas/tribuna/PsfTito.htm

Fundação SEADE. [homepage na Internet]. São Paulo; c2007 [citado 2007 abr. 28]. Disponível em: http://www.seade.gov.br (Dados sobre a Distribuição dos Óbitos de Homens entre 10 e 49 anos, por Principais Agrupamentos de Causas, segundo Subprefeituras e Equipamentos Culturais, por Tipo, segundo Subprefeituras e Distritos do Município de São Paulo).

Lancetti $A$, coordenador. Saúdeloucura 7: saúde mental e saúde da família. 2ª ed. São Paulo: Hucitec; 2000. 
Levy FM, Matos PES, Tomita NE. Programa de Agentes Comunitários de Saúde: a percepção de usuários e trabalhadores da saúde. Cad Saúde Pública. 2004;20(1): 197-203.

Lima CRM. Reforma do estado e política de saúde: discussão da agenda do Banco Mundial e da crítica de Laurell. Saúde Debate. dez. 1995-mar. 1996;49:34-43.

Maragno L, Goldbaum M, Gianini RJ, Novaes HMD, César CLG. Prevalência de transtornos mentais comuns em populações atendidas pelo Programa Saúde da Família (QUALIS) no Município de São Paulo, Brasil. Cad Saúde Pública. 2006; 22(8):1639-48.

Mari JJ, Jorge MR. Epidemiologia dos transtornos mentais. In: Mari JJ, Razzouk D, Peres MFT, Del Porto JA. Psiquiatria. Barueri: Manole; 2002. p. 1-5.

Martines WRV. Compreendendo o processo de sofrimento no trabalho do agente comunitário de saúde no programa saúde da família [dissertação]. São Paulo (SP): Escola de Enfermagem, Universidade de São Paulo; 2005.

Minayo MCS. O desafio do conhecimento: pesquisa qualitativa em saúde. São Paulo: Hucitec; 1992.

Misoczky MC. A agenda para reformas do Banco Mundial e a política de saúde: algumas notas para reflexão. Saúde Debate. 1995;47:4-7.

Nascimento BA. O mito da atividade terapêutica. Revista de Terapia Ocupacional- v.1, n.1- USPS-SP: ago/90. p.17-21.

Nascimento AAM, Braga VAB. Atenção em saúde mental: a prática do enfermeiro e do médico do Programa Saúde da Família de Caucaia-CE. Cogitare Enferm., Curitiba, v.9, n.1, jan/jun. 2004. p.84-93.

Nunes MO, Trad LB, Almeida BA, Homem CR, Melo MCIC. O agente comunitário de saúde: construção da identidade desse personagem híbrido e polifônico. Cad Saúde Pública. 2002;18(6):1639-46.

Organização Mundial de Saúde. Organização Pan-Americana de Saúde, Centro Brasileiro de Classificação de Doenças, Faculdade de Saúde Pública da Universidade de São Paulo. Centro Colaborador da OMS para a Classificação de Doenças em Português. Implementação para disseminação eletrônica efetuada pela FNS - DATASUS - Departamento de Informática do SUS, 1993. (Capítulo V: Transtornos mentais e comportamentais (F00-F99)

Organização Mundial de Saúde. Organização Pan-Americana de Saúde. Relatório sobre a saúde no mundo, 2001: saúde mental: nova concepção, nova esperança. Genebra; 2001. 
Pereira MAO. Representação da doença mental pela família do paciente. Interface Comunic Saúde Educ. 2003;7(12):71-82.

Rotelli F. A instituição inventada. In: Rotelli F, Leonardis O, Mauri D, Risio C. Desinstitucionalização. São Paulo: Hucitec; 1990. p. 89-99.

Rotelli F, De Leonardis O, Mauri D. Desinstitucionalização, uma outra via. In: Rotelli F, Leonardis O, Mauri D, Risio C. Desinstitucionalização. São Paulo: Hucitec; 1990. p. 17-59.

Salum MJL. A responsabilidade da universidade pública no processo institucional de renovação das práticas de saúde: questões sobre o programa de saúde da família [texto na Internet]. Brasília: [s.n.]; 2001.

Santos NO, Kretzer MR, Matos MPSA. O Território de atuação. In: Fernandes MEL et al. Aids: Prevenção porta a porta: construindo histórias de prevenção ao HIV/AIDS no Programa Saúde da Família da cidade de São Paulo. São Paulo: Hucitec; 2004. p. 55-9.

Santos RMB. Projeto Qualidade Integral em Saúde (QUALIS): relato de uma experiência : abril de 1996 a junho de 1999 [dissertação]. São Paulo (SP): Faculdade de Saúde Pública, Universidade de São Paulo; 2001.

São Paulo (cidade). Prefeitura Municipal. Vila Prudente/Sapopemba. Como a cidade ocupou as velhas fazendas da Zona Leste, 2005 [texto na Internet]. São Paulo: PMSP; 2005a [citado 2005 nov. 7]. Disponível em: www.prefeitura. sp.gov.br

São Paulo (cidade). Prefeitura Municipal. Vila Prudente/Sapopemba Região Leste. Sumário de Dados 2004 [texto na Internet]. São Paulo: PMSP; 2005b [citado 2005 nov. 7]. Disponível em: www.prefeitura. sp.gov.br

São Paulo (cidade). Secretaria Municipal de Saúde. Coordenadoria de Epidemiologia e Informação (CEInfo). Diagnóstico mínimo por Coordenadoria Regional de Saúde - Município de São Paulo - Abril de 2005 [texto na Internet]. São Paulo: SMS; 2005c [citado 2005 dez. 13]. Disponível em: www.prefeitura. sp.gov.br

São Paulo (cidade). Secretaria Municipal da Saúde. Atenção Básica e PSF. Documento Norteador. Compromissos das Unidades Básicas de Saúde com a População. São Paulo: Abril de 2005d.

Saraceno B, Asioli F, Tognoni G. Manual de saúde mental: guia básico para atenção primária. $2^{\mathrm{a}}$ ed. Trad. de Willians Valentini. São Paulo: Hucitec; 1997. 
Saraceno B. Libertando identidades: da reabilitação psicossocial à cidadania possível. Belo Horizonte: Te Cora; 1999.

Saraceno B. Reabilitação Psicossocial: uma estratégia para a passagem do milênio. In: Pitta A (organizadora), Reabilitação Psicossocial no Brasil. São Paulo: Hucitec, 2001. p.13-18.

Silva J, Dalmaso ASW. Agente comunitário de saúde: o ser, o saber, o fazer. Rio de Janeiro: Editora FioCruz; 2002.

Silveira DP. Sofrimento psíquico e serviços de saúde: cartografia da produção do cuidado em saúde mental na atenção básica de saúde [dissertação] Rio de Janeiro: s.n., 2003. Fundação Oswaldo Cruz, Escola Nacional de Saúde.

Souza Filho EA. Análise de Representações Sociais. In: Spink MJ (organizadora). O conhecimento no cotidiano: as representações sociais na perspectiva da Psicologia Social. São Paulo: Brasiliense, 1995 - parte 1, p.109-45.

Souza MLP. Expansão do Programa Saúde da Família (PSF) e identificação de problemas relacionados ao uso de álcool no Brasil. Rev Bras Psiquiatr. 2005; 27(4):342-3.

Takahashi RF, Oliveira MAC. A operacionalização do conceito de vulnerabilidade no contexto da saúde da família. In: Brasil. Instituto para o Desenvolvimento da Saúde. Universidade de São Paulo. Ministério da Saúde. Manual de enfermagem: Programa Saúde da Família. Brasília; 2001. p. 225-8.

Tomaz JBC. O agente comunitário de saúde não deve ser um "super-herói". Interface Comunic Saúde Educ. 2002;6(10):75-94.

Weber CAT. Programa Saúde da Família: educação e controle da população. Porto Alegre: AGE; 2006.

Zanchetta M, Leite L, Perreault M, Lefebvre H. Educação, crescimento e fortalecimento profissional do Agente Comunitário de Saúde: estudo etnográfico. Online Braz J Nurs [periódico na Internet]. 2005 [citado 2007 abr. 30]; 4;(3):[cerca de 14 p.]. Disponível: http://www.uff.br/objnursing/viewarticle.php?id=74. 


\section{ANEXOS}

\section{I. MAPA DO MUNICÍPIO DE SÃO PAULO}

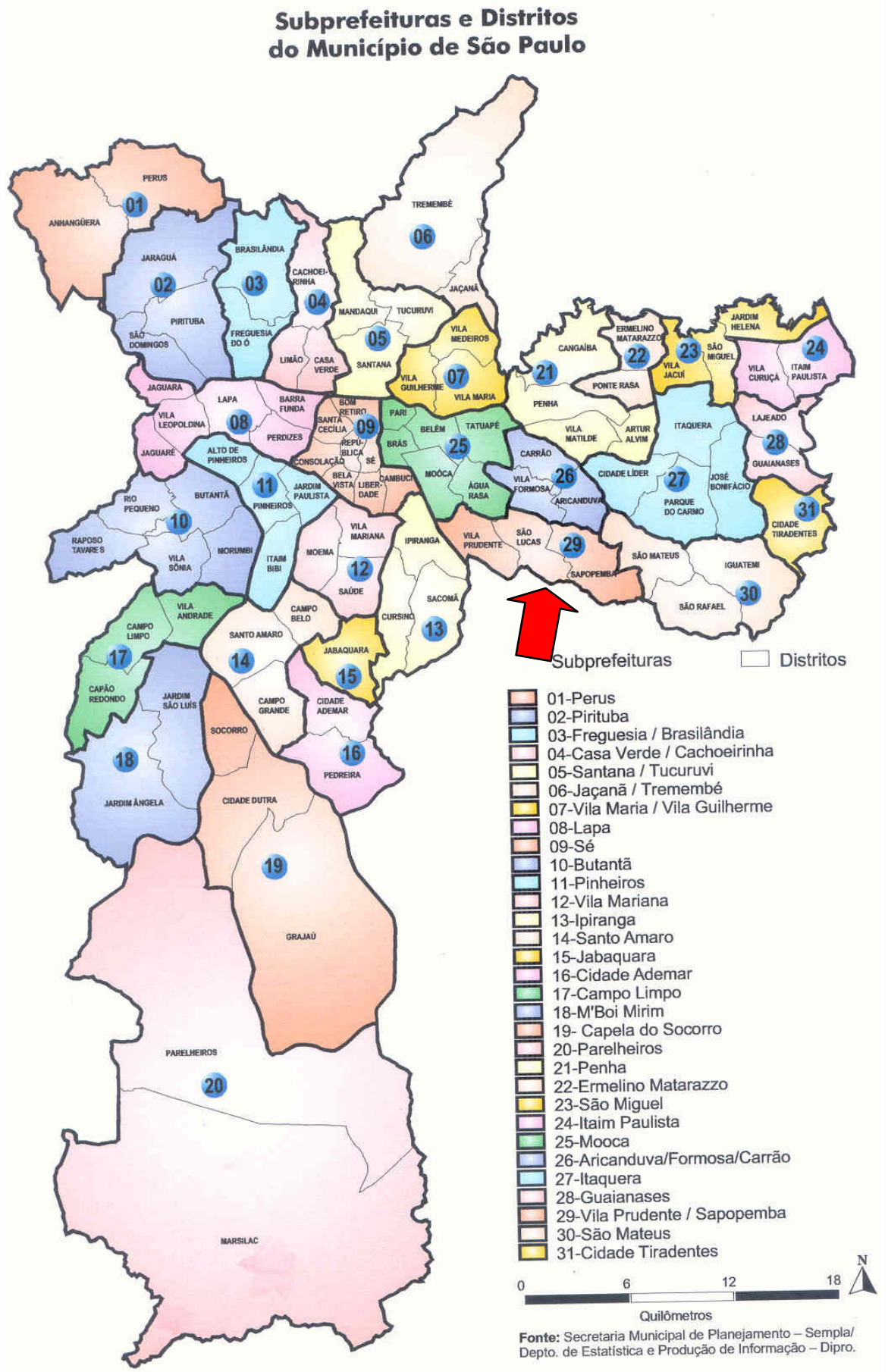




\section{TERMO DE CONSENTIMENTO LIVRE ESCLARECIDO}

Eu, Gianne Carvalho de Sousa, psicóloga, aluna do Programa de Pós-Graduação da Escola de Enfermagem da Universidade de São Paulo - Nível Mestrado, estou realizando uma pesquisa com o objetivo de identificar os significados e práticas dos Agentes Comunitários de Saúde do Programa Saúde da Família em relação ao sofrimento mental. Para tanto, gostaria de contar com a sua colaboração durante alguns minutos para realizar uma entrevista que será gravada e, posteriormente, transcrita para melhor análise dos dados que ficarão sob total responsabilidade da pesquisadora a fim de preservar o sigilo necessário.

Sua participação é voluntária e é importante deixar claro que poderá desistir em qualquer momento, sem que isso tenha qualquer consequiência negativa para você.

Asseguro que todas as informações prestadas por você são sigilosas, serão utilizadas somente para esta pesquisa e sua identidade será preservada, ou seja, a divulgação das informações enfatizará o conteúdo relatado e não a identidade do entrevistado.

Se você tiver alguma pergunta para esclarecer sobre a pesquisa ou sobre sua participação, sinta-se à vontade para fazê-la, ficando também a Coordenação Técnica Regional - Região Sudeste - PSF Fundação Zerbini à disposição para esclarecimentos adicionais.

Qualquer contato com a pesquisadora poderá ser feito pessoalmente na Unidade de Saúde Reunidas I, via telefone desta U.S. (11) 6702-1777 ou celular (11) 9657-7856.

Data: / /

Nome do Entrevistado:

Assinatura do Entrevistado:

Nome do entrevistador: Gianne Carvalho de Sousa

Assinatura do entrevistador: 


\section{QUESTÕES NORTEADORAS DAS ENTREVISTAS}

1. Descreva os problemas de saúde que você encontra na sua área.

2. Já identificou alguma situação de sofrimento mental? Como foi?

3. As famílias solicitam atendimento quando passam por situação de sofrimento mental? Para que tipo de situação? E como você encaminha estas solicitações?

4. Há situações que você identifica que são de sofrimento mental sem a família falar sobre o assunto? Como você identifica estas situações? O que faz quando isto ocorre?

5. Sua ESF tem referência de saúde mental há quanto tempo?

6. Como é o trabalho de saúde mental em sua USF?

7. Fora do trabalho, você já se deparou com situação de sofrimento mental? Como foi?

8. É possível tratar alguém com sofrimento mental? Como?

9. Por que você acha que as pessoas passam por este tipo de sofrimento? 